\title{
Bagaimana menggunakan Program AVSIM51 Versi 1.30 untuk Simulasi Mikrokontroller 8031
}

\author{
Oleh Andi Susilo
}

\begin{abstract}
AVSIM51 Utility Program will help you to simulate your regulation system project with MCS51 Microcontroller family. Here we use minimum system of Microcontroller 8031. Source code to control the system will be saved in EPROM. Before you write assembler program to EPROM, simulate code with AVSIM51 Simulator to see system behaviour, it really doesn't take much time. If code works properly you could continue to write EPROM by using EPROM Programmer. Otherwise edit the code and try to simulate again until no failure found. And finally system will work as well as you want.
\end{abstract}

\section{Pendahuluan}

Program Bantu AVSIM51 digunakan untuk mensimulasikan operasi internal mikrokontroller, melalui pengamatan SFR (Special Function Register) dan operasi pada memori data. Melalui program bantu simulasi ini, sebelum program disimpan ke dalam EPROM, program yang telah dibuat dapat duji apakah telah sesuai dengan operasi kerja yang diinginkan, memeriksa isi register, memori data, alamat yang digunakan, penggunaan perangkat instruksi yang sesuai dan modus pengalamatan. Sehingga tidak perlu lagi mengisi EPROM berulangkali hanya karena program belum berjalan sesuai keinginan pembuat program.

Bagaimana menggunakan Program AVSIM51 Versi 1.30 untuk Simulasi Mikrokontroller 8031 (Andi Susilo) 
Untuk berlatih menggunakan program bantu ini, perlu mencoba beberapa program singkat dengan modus pengalamatan yang sesuai. Program AVSIM51 yang digunakan disini adalah dibawah sistem operasi DOS. Apabila diperlukan bisa menghubungi penulis untuk meng-copy program Bantu AVSIM51 versi 1.30 membutuhkan hanya satu disket dengan beberapa contoh program yang telah diujicobakan.

Didalam system operasi DOS pada prompt DOS, eksekusi file AVSIM51.exe, jika file tersebut berada didalam direktori: C:\AVSIM51\dir01, maka ketikkan pada prompt: C:\AVSIM51\dir01\AVSIM51 (enter).

\section{AVSIM 8051 Simulator/Debugger}

Serial \# 01036 Licensed by Avocet Systems, Inc.

Copyright $\odot 1984,1985,1986$ by Ken Andersen Software All Rights Reserved

Intel 8051 Family Microcomputers

\section{HMOS ROM}

A: $\quad 8051 / 8751$

B: $\quad 8052 / 8752$
HMOS ROMless

C: $\quad 8031$

D: $\quad 8032$
CMOS ROM

E: $\quad 80 C 51$

F: $\quad 80 \mathrm{C} 31$

Choose a CPU for simulation :

Gambar 1 Tampilan awal program Simulator AVSIM51

Apabila menggunakan Sistem Operasi berbasis Windows seperti Windows 95 keatas, jalankan Windows Explorer, carilah file AVSIM51.EXE melalui direktori yang sesuai dan klik dua kali pada file

18 Majalah Ilmiah Informatika, Vol. 4, No. 13, Desember 2002, Hal. 17-77 
tersebut, jika dengan cara ini tidak berhasil, kemungkinan program membutuhkan eksekusi melalui sistem operasi DOS, dari menu pilih Start $\rightarrow$ Programs $\rightarrow$ MS-DOS Prompt dan jalankan program dari direktori yang sesuai. Setelah program berhasil dipanggil, tampilan awal program terlihat seperti pada gambar 1 .

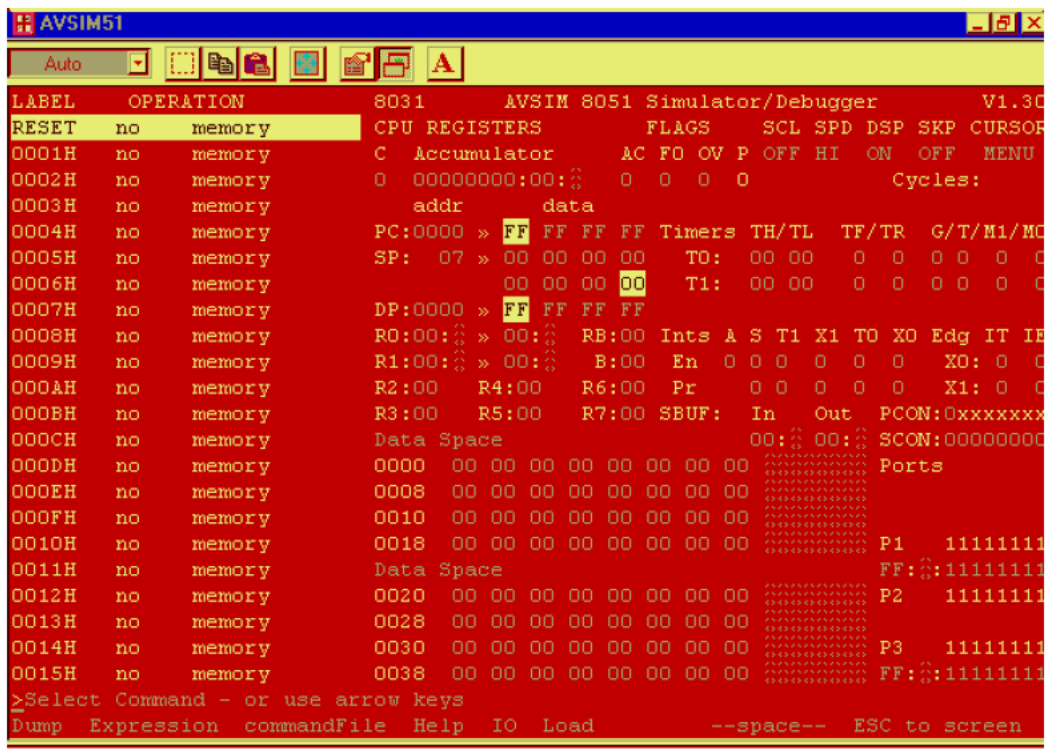

Gambar 2 tampilan menu utama program Simulator AVSIM51

Pilih C untuk simulasi Mikrokontroller 8031, berikutnya program akan menampilkan window tampilan utama AVSIM51 seperti terlihat pada gambar 2 terdiri dari register dengan fungsi (SFR), ruang data (Data Space), label sebagai tempat alamat program dan operation bagian opcode 
yang ditulis dinamakan fragmen program, pada bagian ini pula program akan ditampilkan, apabila menulis satu bagian opcode atau keseluruhan.

Ketika program AVSIM51 dijalankan, program ini melaksanakan simulasi didalam memori, seluruh perangkat keras dari chip target, termasuk seluruh register, port-port, memori dan periferal. Program AVSIM51 versi 1.30 yang terlihat pada gambar 2 dijalankan melalui sistem operasi Windows 95 OSR 2. Kode yang dirakit (assembled code) dapat dieksekusi dari chip target dan mengamati kondisi CPU ketika kode dieksekusi. AVSIM51 menyediakan tampilan CPU yang lengkap dimana bisa diamati kode yang dieksekusi, satu opcode dalam satu waktu, mengamati efek dari tiap-tiap opcode pada register-register, port-port dan alamat memori CPU target.

AVSIM51 juga menyediakan debugger simbolik (Symbolic Debugger) yang lengkap. Anda dapat mengatur breakpoints atau passpoints, single-step sepanjang kode, membatalkan operasi, menguji dan merubah register-register, memori dan flag, hanya dengan simbolik debugger.

\section{Tutorial}

\section{Menggunakan kunci fungsi}

Tiga kunci simulasi dasar adalah $\langle\mathrm{GO}\rangle \mathrm{F} 1$, $\langle$ SSTEP $\rangle \mathrm{F} 10$ dan $<\mathrm{UNDO}>\mathrm{F} 9$, ketika menekan F1, simulator mulai berjalan pada alamat yang ditentukan di dalam Program Counter (PC), AVSIM51 mengeksekusi program opcode demi opcode. Seluruh Register-register, port-port dan memori yang terkait berubah, jika program menemukan sebuah breakpoint maka eksekusi akan berhenti, kondisi default tampilan

20 Majalah Ilmiah Informatika, Vol. 4, No. 13, Desember 2002, Hal. 17-77 
berubah setelah opcode dieksekusi. Bisa pula mematikan display dan memilih window untuk perubahan (Update) dengan $\langle$ DSP $>$ F6 dan $<$ TRACE >Alt-F6. Mengatur kecepatan perubahan display dengan $<$ SPD $>$ F5. Kunci ini memilih tiga tingkat kecepatan simulasi yaitu LOw, MEDium dan HIgh. <SSTEP>F10 mengeksekusi satu opcode (di alamat yang dispesifikasikan oleh PC), jika program ingin dihentikan oleh sebuah breakpoint gunakan $<$ SSTEP $>$ F10 untuk melewati breakpoint.

Dalam kondisi default AVSIM51 mengeksekusi subrutin tahap demi tahap. Jika tidak menginginkan eksekusi single-step sebuah subrutin (Ketika subrutin bekerja dengan baik dan user hanya tertarik kepada bagian utama program), gunakan $\langle\mathrm{SKP}\rangle \mathrm{F} 8$ untuk melewati subrutin. Ketika SKP dalam kondisi ON, AVSIM51 akan berjalan dengan kecepatan penuh melalui subrutin masing-masing. Ketika SKP dalam kondisi OFF, dapat dilaksanakan single-step melalui subrutin. Ketika SKP dalam kondisi ON dan Anda melaksanakan operasi single-step pada sebuah subrutin Call, subrutin akan mengeksekusi dengan kecepatan penuh dan simulator akan berhenti tepat sebelum instruksi berikutnya. Ketika proses ini selesai dapat dilanjutkan melaksanakan single-step melalui program kembali, hal yang perlu diingat bahwa subrutin mengeksekusi secara normal seluruh register, port dan seterusnya.

<UNDO>F9 membatalkan eksekusi opcode terakhir. PC dikembalikan kepada instruksi sebelumnya, seluruh register, port dan memori dikembalikan ke kondisi semula dari opcode yang dibatalkan eksekusinya. Jika menggunakan file I/O akan secara benar melaksanakan pembatalan. Hanya passpoint yang tidak dikembalikan oleh $\langle$ UNDO $>$ F9.

Bagaimana menggunakan Program AVSIM51 Versi 1.30 untuk 21 Simulasi Mikrokontroller 8031 (Andi Susilo) 
Anda dapat mengatur ukuran dari stack undo sesuai keinginan dengan mengatur perintah Undo pada menu utama. Ketika memilih pilihan ini, perintah tersebut akan menanyakan ukuran buffer Undo. Jika pemakai mencoba untuk melampaui batasan, AVSIM51 akan menampilkan pesan peringatan "Sorry, CAN'T UNDO"

Kunci breakpoint. Kunci breakpoint mengijinkan pengaturan sementara breakpoint pada fragmen program yang ditampilkan. Ketika menekan kunci kursor breakpoint, $\langle\mathrm{BKUP}\rangle \mathrm{F} 2$ atau $\langle\mathrm{BKDN}\rangle \mathrm{F} 4$, kursor breakpoint akan muncul. Kursor breakpoint ditunjukkan dengan sebuah segitiga terang. Tekan $\langle\mathrm{BKUP}\rangle \mathrm{F} 2$ atau $\langle\mathrm{BKDN}\rangle \mathrm{F} 4$ untuk menggerakkan kursor breakpoint, ketika diposisikan disamping opcode yang ingin diperangkap, tekan $\langle\mathrm{BKST}>\mathrm{F} 3$, segitiga akan berubah menjadi tanda panah kecil. Ketika program berjalan, program akan dihentikan saat mencapai breakpoint. Breakpoint ini adalah dinamik, breakpoint akan mereset sendiri setelah memerangkap program. Untuk mengatur lebih banyak breakpoint permanen dan menggunakan breakpoint terkondisi atau penunda, gunakan menu Set.

Scroll Lock. Dalam kondisi default, kursor simulator bergerak dari window ke window saat diketikan, cara ini sesuai ketika pemakai mengubah nilai-nilai berbeda pada window-window yang berbeda. Bagaimanapun juga membutuhkan waktu ketika mengharapkan kesesuaian untuk membatasi kursor dalam satu window. Sebagai contoh saat sedang mengubah sebuah area dump data, akan lebih mudah untuk mendapatkan kursor pada baris kedua area dump, daripada melalui port area. Atau, ketika mensimulasikan masukan dari keyboard, bisa mengunci kursor pada

22 Majalah Ilmiah Informatika, Vol. 4, No. 13, Desember 2002, Hal. 17-77 
window ASCII port dan menuliskannya tanpa secara terus-menerus kembali ke port.

$<$ SCLTOG >Ctrl-PgUp men-toggle kursor antara dua mode, untuk membatasi kursor pada daerah window, tekan Ctrl-PgUp, kursor kemudian akan membatasi window tersebut. Tekan <SCLTOG> Ctrl-PgUp untuk mematikan pengunci kursor (cursor lock). Daerah dump data akan menggulung, ketika mencapai byte terakhir dari area, delapan byte berikutnya akan ditampilkan.

\section{Mempelajari Perangkat Instruksi 8031}

1. Dari menubar pilih perintah eXecute (atau tekan huruf besar X). Penjelasan menu ini adalah Eksekusi langsung instruksi Mnemonic (Direct Execution of Mnemonic Instruction).

Menuliskan sebaris program berikut dengan pengalamatan langsung, pada bagian pengisian. Enter Mnemonic: MOV A,\#22H Enter, mengisi akumulator dengan data $22 \mathrm{H}$. Untuk pengalamatan langsung harus menggunakan simbol \#. Hasil eksekusi program dari register Akumulator ditampilkan dalam bentuk Biner dan Heksa:

Accumulator

$00100010: 22$

2. Sekarang tuliskan perintah mnemonic MOV DPTR,\#FF13H (Enter), misalnya alamat FF13H digunakan sebagai alamat control word dari PPI8255, alamat ini harus diletakkan pada register DPTR (Data Pointer).

Bagaimana menggunakan Program AVSIM51 Versi 1.30 untuk 23 Simulasi Mikrokontroller 8031 (Andi Susilo) 
Amatilah register yang ditunjukkan pada DP, register ini sekarang berisi $\mathrm{FF} 13 \mathrm{H}$, tampilan program terlihat DP:FF13

3. Sekarang cobalah berlatih untuk menuliskan lebih banyak mnemonic dari perangkat instruksi 8031 berikut, secara berurut menggunakan perintah eXecute dan amati perubahan isi register yang dioperasikan padanya. Untuk operasi aritmatika seperti SUBB, ADD, ADDC dan lain-lain, perhatikan secara teliti isi dari register Flag dan Carry Flag (C) yang diletakkan terpisah pada tampilan program.

MOV R1,A ; Mengisi register R1 dengan data dari register

MOV P1,R1 ; isi register R1 dikirim ke port 1

INC@R1 ; Tambahkan satu, data pada alamat yang ; ditunjukkan oleh register R1

INC R1

SETB C ; Tambahkan isi register R1 dengan satu

SUBB A,\#03H ; Kurangkan Akumulator dengan 03H

ADD A, @R1

; Tambahkan Akumulator dengan data pada ; alamat yang ditunjukkan oleh register R1

MOV PSW,\#OOH ; Mengisi register PSW dengan 00H, ; $\mathrm{RS} 1=0$ dan $\mathrm{RS} 0=0$

MOV R0,\#01H ; Menempatkan data $01 \mathrm{H}$ pada alamat R0 ; untuk Bank 0 dalam lokasi memori 00H-07H

MOV PSW, \#08H ; Mengisi register PSW dengan 08H, ; $\mathrm{RS} 1=0$ dan $\mathrm{RS} 0=1$

MOV R0,\#01H $\quad$; Menempatkan data 01H pada alamat R0 untuk ; Bank 1 dalam lokasi memori 08H-0FH

CLR P1.0 ; Reset bit P1.0 dari port 1

MOV IE,\#84H $\quad$; Memungkinkan masuknya interupsi 1

MOV IP,\#04H ; Prioritaskan interupsi 1

SETB TR0 $\quad$; Set bit TR0 untuk mengaktifkan timer 0

MOV TMOD,\#01H ; Timer 0 dipicu oleh perangkat lunak, dengan

; masukan dari Clock internal dalam Mode 1

; yaitu Timer/Counter 16 bit

MOV TH0,\#0D8H ; Mengisi register TH0 dengan D8H

MOV TL0,\#OEFH ; Mengisi register TL0 dengan EFH

24 Majalah Ilmiah Informatika, Vol. 4, No. 13, Desember 2002, Hal. 17-77 
IV. Melihat Register Fungsi Khusus dan Alamatnya

Pada bagian ini diperlihatkan register-register fungsi khusus yang terdapat pada mikrokontroler 8031, juga penjelasan tentang Breakpoints, Passpoints, Symbols dan IO-files.

\subsection{Symbols}

1. Menampilkan dari menubar View $\rightarrow$ Symbols $\rightarrow$ Code, menampilkan alamat rutin pelayanan interupsi. Mikrokontroler 8031 tidak memiliki Timer 2 (Timer 2 dimiliki oleh Mikrokontroler 8032). Tekan Enter untuk melanjutkan atau Ctrl-C untuk membatalkan.

2. Untuk menampilkan simbol-simbol dari register, jalankan perintah dari menubar :

View $\rightarrow$ Symbols $\rightarrow$ Registers tekan Enter

3. Menampilkan alamat dari register serbaguna R0 sampai R7, menurut definisi yang ditentukan dari register PSW (Program Status Word) yaitu bit pemilih alamat RS1 dan RS0, Bank 0 memiliki lokasi memori 00H-07H, Bank 1 lokasi memori 08H-0FH, Bank 2 lokasi memori 10H-17H dan Bank 3 dengan lokasi memori 18H-1FH

4. Menampilkan register fungsi khusus pada mikrokontroler 8031, pilih dari menubar dengan cara : View $\rightarrow$ Symbols $\rightarrow$ SFR tekan Enter

5. Menampilkan alamat bit dari setiap register fungsi khusus, perhatikan tiap-tiap bit memiliki alamat tersendiri. Sebagai contoh untuk register IE (Interrupt Enable Control) memiliki alamat A8H, dimana merupakan alamat awal dari bit EX0, A9H untuk bit ET0 (IE.1) dan seterusnya. Pilih dari menubar View $\rightarrow$ Symbols $\rightarrow$ Bit tekan Enter

Bagaimana menggunakan Program AVSIM51 Versi 1.30 untuk 
6. Menampilkan simbol-simbol dan alamat-alamat dari setiap bit SFR dan register serbaguna. Pilih dari menubar View $\rightarrow$ Symbols $\rightarrow$ Alpha dan tekan Enter

\subsection{Breakpoints}

Perintah breakpoints menampilkan seluruh breakpoints yang diatur oleh pengguna dalam urutan naik berdasarkan alamat. Breakpoints ditampilkan pada layar dalam format kolom berikut :

BKPT Addr EndAddr Access Life Delay/Count Condition

Keterangan :

1. Addr : Alamat awal breakpoint, jika memungkinkan ditampilkan secara simbolik.

2. EndAddr : Alamat akhir dari jangkauan breakpoint, nilai ini sama dengan alamat awal jika tidak memiliki sebuah range.

3. Access : Jenis Akses yaitu Read/Write (R/W) atau Write-Only (W-O).

4. Life : Jenis Life yaitu "Sticky" (Permanen) atau "Dynamic" (hanya satu saat).

5. Delay/Count : Memperlihatkan delay jika ada, dan jumlah waktu dari program yang telah dilewatkan melalui breakpoint atau passpoint.

6. Condition.

\subsection{Passpoints}

Passpoints identik dengan breakpoints, dengan satu pengecualian yaitu tidak menangkap eksekusi ketika kondisi ditemukan, sebuah counter 32 bit dinaikkan. Hal ini mengijinkan user untuk memonitor penggunaan memori dan utiliti subrutin, tanpa interferensi dengan proses program.

26 Majalah Ilmiah Informatika, Vol. 4, No. 13, Desember 2002, Hal. 17-77 
Passpoints diatur dan direset dengan cara yang sama dilakukan kepada "sticky" (Permanen) breakpoints. Untuk melihat counter yang sedang berlangsung pilih dari menubar View $\rightarrow$ Passpts dan tekan Enter.

\subsection{I/O Files}

Sebagian besar program biasanya menanggapi masukan eksternal dan membangkitkan beberapa bentuk keluaran. Keuntungan penggunaan sebuah Emulator rangkaian melalui teknik simulasi adalah lingkungan eksternal mikrokomputer dikondisikan dan fungsional. Emulator rangkaian membantu dalam manipulasi rangkaian mikroprosesor sesungguhnya untuk operasi I/O.

Sebuah lingkungan yang tersimulasi harus menyediakan beberapa bentuk dari I/O tersimulasi untuk menguji tanggapan CPU terhadap peralatan eksternal. AVSIM51 menggunakan dua teknik untuk menyediakan I/O tersimulasi yaitu Interaktif I/O dan File I/O.

Interaktif I/O mengijinkan user memanipulasi port I/O secara manual sementara simulasi program bekerja. Kelebihan dari teknik ini adalah bisa menciptakan kombinasi masukan apapun yang diinginkan, beberapa diantaranya mungkin sangat sulit untuk dapat diterapkan pada rangkaian sesungguhnya.

Files I/O mengijinkan user mensimulasikan masukan dari peralatan eksternal dari sebuah file data sekuensial. AVSIM51 menggunakan sebuah file I/O yang diorganisasikan sebagai sebuah aliran (stream) data 8 bit. Data secara normal diukur dalam byte seperti keluaran keyboard atau keluaran konverter A/D yang dihubungkan ke port.

Bagaimana menggunakan Program AVSIM51 Versi 1.30 untuk 
Bisa juga menghubungkan sebagian atau keseluruhan bit I/O dari file program ke setiap bit dari port manapun ke alamat yang didefinisikan di dalam memori target atau bahkan ke pseudo-register "PINS". Sebuah nilai I/O yang dipilih pengguna menspesifikasikan kecepatan (di dalam siklus mesin CPU target) dimana aliran data dibaca.

Pada umumnya mikroprosesor memiliki dua bentuk I/O yaitu Interupsi dan polled. I/O yang dikendalikan melalui interupsi berguna dalam situasi dimana I/O muncul sementara proses sedang dijalankan, tetapi data yang masuk harus di proses secara cepat. Proses-proses akan diinterupsi ketika I/O dilaksanakan dan proses berjalan kembali, setelah rutin I/O selesai dikerjakan. Polled I/O lebih berguna ketika I/O muncul di setiap waktu, tetapi data dapat diabaikan sampai program siap untuk memprosesnya.

AVSIM51 menyediakan kedua bentuk I/O tersebut. I/O yang dikendalikan dengan interupsi dapat disinkronisasikan untuk mengatur jumlah dari siklus mesin. User dapat mengatur siklus mesin yang cukup rendah untuk menangkap hampir setiap terjadinya interupsi. Dengan catatan, bahwa I/O ditunjukkan pada sebuah preset I/O rate dan tidak disinkronisasikan kepada kejadian-kejadian internal. Anda harus bereksperimen dengan menentukan sejumlah siklus untuk menemukan sebuah nilai yang dianggap sesuai pada nilai penting.

Polled I/O disimulasikan oleh Opcode access didalam AVSIM51. Simulator mengijinkan user menentukan sebuah file masukan atau keluaran ke sebuah register atau port. Kapanpun sebuah opcode menulis ke atau membaca dari alamat ini, sebuah file I/O diakses.

28 Majalah Ilmiah Informatika, Vol. 4, No. 13, Desember 2002, Hal. 17-77 
Secara kebetulan File I/O mungkin diciptakan dengan cara yang user pilih sendiri oleh sebuah program atau dengan teks editor. Pembatasan satu-satunya adalah file harus dalam bentuk file sekuensial. Seharusnya tidak menambahkan sebuah carriage yang dikembalikan ke data atau menggunakan teks editor yang menempatkan karakter kontrol ke dalam file, karena akan ditafsirkan sebagai data oleh AVSIM51. Kebanyakan pengolah kata membolehkan User menyimpan sebuah file sebagai file ASCII secara langsung. User dapat menggunakan pilihan ini untuk menciptakan sebuah file data. Sebuah file mungkin digunakan lebih dari satu kali dan digunakan baik sebagai bit atau byte masukan.

Simulator dapat diatur untuk menangkap eksekusi program atau untuk mengembalikan ke awal ketika mencapai akhir dari file masukan. Sebagai contoh, untuk mensimulasikan sebuah gelombang kotak $1 \mathrm{KHz}$, Anda menciptakan sebuah file teks yang berisi string "01" (ASCII $30 \mathrm{H}$, 31H) dan meletakkan bit rendah ke sebuah pena masukan dari mikrokomputer yang disimulasikan. Aturlah nilai perulangan pada "kecepatan clock/2000" dan pilih untuk mengembalikan akhir file (EOF) dengan pilihan "Y", ketika sebuah simulasi program berjalan, pena masukan akan dikendalikan tinggi dan rendah menurut nilai frekuensi 1 $\mathrm{KHz}$ yang disimulasikan.

User juga mampu mengirimkan data keluaran ke peralatan eksternal ke dalam CPU yang disimulasikan. Data keluaran ini dapat disimpan di dalam sebuah file dan dapat diuji atau digunakan kemudian, aliran data keluaran 8 bit dihasilkan pada nilai I/O yang dispesifikasikan, untuk membentuk 8 bit keluaran, Anda mengkombinasikan bit-bit dari

Bagaimana menggunakan Program AVSIM51 Versi 1.30 untuk 29 Simulasi Mikrokontroller 8031 (Andi Susilo) 
port-port yang berbeda. Misalnya, mengkombinasikan 4 bit rendah dari P1 dan 4 bit tinggi dari P2. Sebagai catatan Anda dapat juga memetakan ulang bit-bit dan dengan mudah mengirimkan 4 bit tinggi P2 menuju 4 bit manapun dari file keluaran.

Satu pembatasan dari file I/O adalah Anda harus mempersiapkan file-file masukan sebelum memulai sebuah bagian simulasi. Hal ini menghalangi kemampuan simulasi umpan balik dari peralatan eksternal. Anda harus mengantisipasi respon-respon CPU ketika mempersiapkan file I/O dan memastikan umpan balik yang benar dengan analisa data keluaran.

Dengan kunci <UNDO>F9, pengguna dapat melangkah maju atau mundur melalui serangkaian interupsi yang dikontrol I/O pada waktu yang tersedia. Sebagai catatan kunci F9 mengembalikan secara benar transfer-transfer file I/O yang mungkin muncul selama eksekusi program. Satu pengecualian, jika file I/O mencapai akhir file (EOF) yang secara otomatis ditutup, kunci F9 tidak dapat membuka ulang file I/O program.

\section{Mereset isi register ke kondisi awal}

1. Pilih dari menubar Reset $\rightarrow \mathrm{CPU}$ tekan Enter

Melaksanakan operasi reset CPU, seluruh isi register diubah sesuai dengan kondisi awalnya. kecuali isi register R0 sampai R7, jika Anda telah mengubahnya maka tidak dapat di reset dengan cara ini, kondisinya terlihat melalui ruang data (data space). Anda dapat mengubahnya ke kondisi awal melalui operasi memori yang akan dijelaskan nanti.

2. Perintah Disptrace mereset seluruh tampilan window trace yang telah diaktifkan. Memanggil kembali di dalam modus display, seluruh window secara otomatis berubah (update), kecuali jika flag display

30 Majalah Ilmiah Informatika, Vol. 4, No. 13, Desember 2002, Hal. 17-77 
(DSP) yang berubah adalah OFF. Ketika flag DSP dalam kondisi OFF, hanya window-window yang telah diatur secara spesifik untuk perubahan (update) yang ditampilkan.

Saat mereset sebuah window, lakukan toggle dari modus display dengan <TRACE> Alt-F6, gunakan perintah ini untuk mereset seluruh modus display window ke OFF. Dari menubar pilih Reset $\rightarrow$ Disptrace dan tekan Enter

3. Perintah cYcles mematikan counter siklus mesin, ketika melaksanakan pilihan ini, tampilan siklus akan terlihat bersinar, tampilan counter siklus mesin tidak akan berubah ketika simulator dijalankan.

\section{Analisa Program secara lengkap}

Setelah mengetahui operasi perangkat instruksi 8031 melalui metode eksekusi langsung, sekarang saatnya untuk membuat beberapa baris program assembler 8031 yang disimpan dalam file dan disimulasikan menggunakan program AVSIM51.

Buatlah program Macro Assembler 8051 untuk mikrokontroler 8031, program ditulis menggunakan salah satu teks editor seperti SideKick, Editor Pascal atau Notepad pada Windows 95. Penulis menggunakan Notepad Windows 95 untuk menulis program, kemudian simpan program dengan ekstension .ASM. Tulislah program dibawah ini menggunakan teks editor.

Bagaimana menggunakan Program AVSIM51 Versi 1.30 untuk 


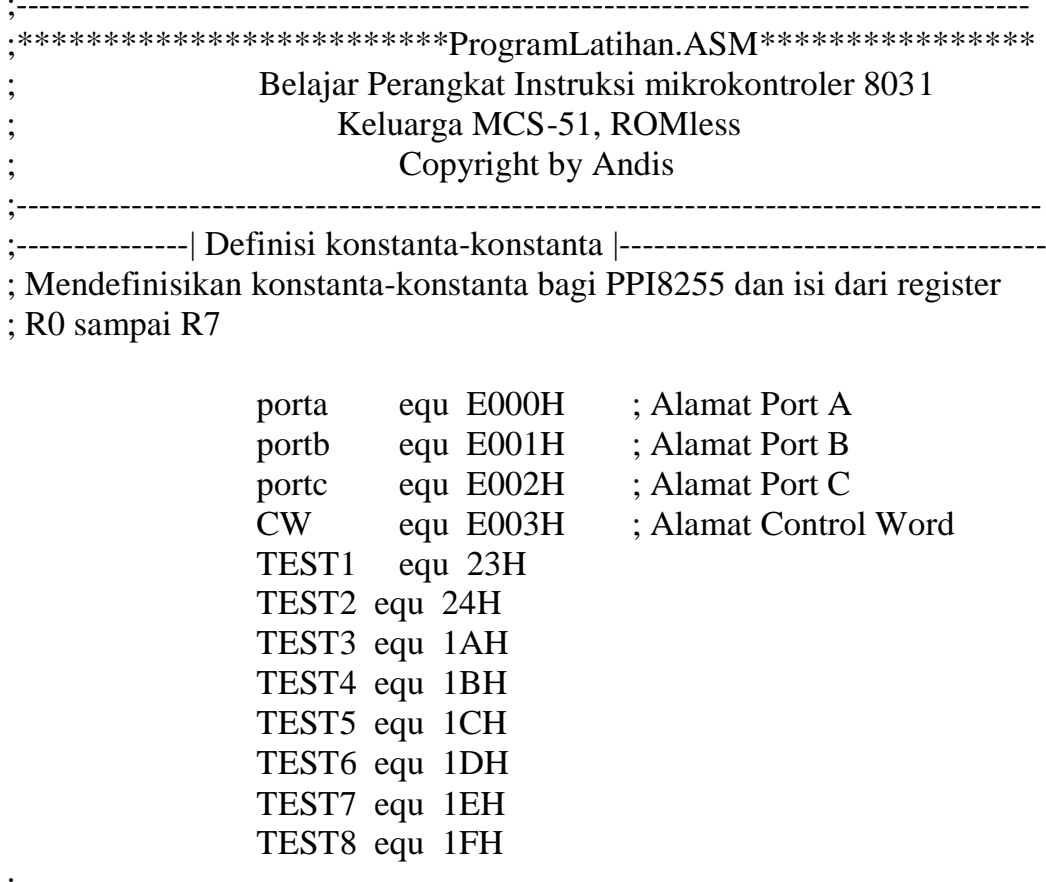

\begin{tabular}{|c|c|c|}
\hline \multirow{9}{*}{ MULAI: } & Org $00 \mathrm{H}$ & ; Alamat awal perintah JMPMULAI \\
\hline & JMP MULAI & ; Menuju label MULAI \\
\hline & $\mathrm{ORG} 40 \mathrm{H}$ & ; Alamat awal program \\
\hline & MOV PSW, \#10H & $\begin{array}{l}\text {; Menggunakan Bank } 2 \\
\text {; dengan lokasi alamat } \\
\text {; 10H-17H }\end{array}$ \\
\hline & MOV DPTR,\#CW & $\begin{array}{l}\text {; Alamat Control Word } \\
\text {; PPI } 8255\end{array}$ \\
\hline & MOV A, \#80H & $\begin{array}{l}\text {; Akumulator berisi data } \\
\text {; inisialisasi } 80 \mathrm{H}\end{array}$ \\
\hline & MOVX @DPTR,A & ; Laksanakan proses \\
\hline & MOV DPTR,\#porta & ; Alamat Port A dari PPI8255 \\
\hline & MOV A, \#55H & $\begin{array}{l}\text {; Akumulator berisi data } 55 \mathrm{H} \\
\text {; untuk dikirim ke port A }\end{array}$ \\
\hline
\end{tabular}

32 Majalah Ilmiah Informatika, Vol. 4, No. 13, Desember 2002, Hal. 17-77 


\begin{tabular}{|c|c|}
\hline MOVX @DPTR,A & ; Laksanakan proses \\
\hline MOV DPTR,\#portb & ; Alamat Port B dari PPI8255 \\
\hline MOV A, \#AAH & $\begin{array}{l}\text {; Akumulator berisi } \\
\text {; data AAH untuk dikirim } \\
\text {; ke port B }\end{array}$ \\
\hline MOVX @DPTR,A & ; Laksanakan proses \\
\hline MOV DPTR,\#portc & ; Alamat Port C dari PPI8255 \\
\hline MOV A, \#55H & $\begin{array}{l}\text {; Akumulator berisi data } 55 \mathrm{H} \\
\text {; untuk dikirim ke port } \mathrm{C}\end{array}$ \\
\hline MOVX @DPTR,A & ; Laksanakan proses \\
\hline MOV P1, \#11H & $\begin{array}{l}\text {; Kirim Port } 1 \text { dengan } \\
\text {;data } 11 \mathrm{H}\end{array}$ \\
\hline MOV P2, \#22H & $\begin{array}{l}\text {; Kirim Port } 2 \text { dengan } \\
\text {; data } 22 \mathrm{H}\end{array}$ \\
\hline MOV P3, \#44H & $\begin{array}{l}\text {; Kirim Port } 3 \text { dengan } \\
\text {; data } 44 \mathrm{H}\end{array}$ \\
\hline MOV R0,\#TEST1 & $\begin{array}{l}\text {; Mengisi R0 dengan nilai } \\
\text {; konstanta TEST1 }\end{array}$ \\
\hline MOV R1,\#TEST2 & $\begin{array}{l}\text {; Mengisi R1 dengan nilai } \\
\text {; konstanta TEST2 }\end{array}$ \\
\hline MOV R2,\#TEST3 & $\begin{array}{l}\text {; Mengisi R2 dengan nilai } \\
\text {; konstanta TEST3 }\end{array}$ \\
\hline MOV R3,\#TEST4 & $\begin{array}{l}\text {; Mengisi R3 dengan nilai } \\
\text {; konstanta TEST4 }\end{array}$ \\
\hline MOV R4,\#TEST5 & $\begin{array}{l}\text {; Mengisi R4 dengan nilai } \\
\text {; konstanta TEST5 }\end{array}$ \\
\hline MOV R5,\#TEST6 & $\begin{array}{l}\text {; Mengisi R5 dengan nilai } \\
\text {; konstanta TEST6 }\end{array}$ \\
\hline MOV R6,\#TEST7 & $\begin{array}{l}\text {; Mengisi R6 dengan nilai } \\
\text {; konstanta TEST7 }\end{array}$ \\
\hline MOV R7,\#TEST8 & ; Mengisi R7 dengan nilai \\
\hline MOV@R0,\#30H & $\begin{array}{l}\text {; konstanta TEST8 } \\
\text {; Mengisi data } 30 \mathrm{H} \text { pada } \\
\text {; alamat yang ditunjukkan } \\
\text {; oleh register R0 }\end{array}$ \\
\hline
\end{tabular}




$\begin{array}{lll} & \text { MOV @R1,\#31H } & ; \text { Mengisi data } 31 \mathrm{H} \text { pada } \\ & & ; \text { alamat yang ditunjukkan } \\ & ; \text { oleh register R1 } \\ \text { ULANG: } & \text { NOP } & ; \text { Tidak ada operasi } \\ & \text { SJMP ULANG } & ; \text { Menuju label ULANG }\end{array}$

Simpan program dengan nama file Latihan.ASM. Sebelum dapat disimulasikan menggunakan AVSIM51, program Latihan.ASM harus diubah menjadi file berekstensi Latihan.HEX, prosesnya sebagai berikut: Latihan.ASM $\rightarrow$ Latihan.OBJ $\rightarrow$ Latihan.HEX

Konversi file berekstensi ASM menjadi berekstensi OBJ menggunakan program X8051 (Macro Assembler 8051), sedangkan konversi file berekstensi OBJ menjadi berekstensi HEX menggunakan program Link (2500 A.D. Linker).

caranya ikuti prosedur berikut :

1. Jalankan file program X8051.EXE, tampilan program awal seperti berikut:

$$
\begin{gathered}
8051 \text { Macro Assembler - Version 4.03C } \\
\text { Copyright (C) } 1985 \text { by } 2500 \text { A.D. Software, Inc. }
\end{gathered}
$$

Listing Destination (N, T, D, E, L, P, $\langle\mathrm{CR}\rangle=\mathrm{N})$ :

Tekan Enter untuk pilihan default N.

2. Tuliskan nama file pada direktori yang sesuai dari pertanyaan :

Input filename : C:\AVSIM51\Latihan.ASM dan tekan Enter, jika file berada pada direktori C:\AVSIM51, spesifikasikan dengan tepat untuk direktori yang lain.

34 Majalah Ilmiah Informatika, Vol. 4, No. 13, Desember 2002, Hal. 17-77 
3. Pertanyaan berikutnya adalah diharuskan mengisi nama file hasil konversi dengan berekstensi OBJ. Jika nama file yang diinginkan sama, cukup tekan Enter, tetapi jika Anda ingin mengganti nama file, tulislah dengan lengkap nama file tersebut berekstensi OBJ.

Output filename : C\AVSIM51LLatihan.OBJ tekan Enter.

Setelah proses konversi nama file berekstensi Latihan.OBJ, selanjutnya akan ditampilkan, keterangan Assembly errors : 0, berarti program yang dibuat menggunakan sintaks yang sesuai atau telah menulis perangkat instruksi 8031 dengan benar.

4. Setelah mendapatkan file berekstensi OBJ, tahap selanjutnya mengubahnya menjadi file berekstensi HEX, jalankan file program Link.EXE, tampilan awal programnya :

2500 A.D. Linker Copyright (C) 1985 - Version 4.03b

Input filename : C:\AVSIM51\Latihan.OBJ tekan Enter Enter Offset For 'CODE' : 0000 tekan Enter

Output filename : tekan Enter (posisi direktori dan nama file sama)

Library filename : tekan Enter

Option (D, S, A, M, Z, X, H, E, T, 1, 2, 3, <CR> Default) : H tekan Enter

Untuk mengubah dengan format HEXA pilih huruf $\mathrm{H}$

Apabila proses konversi berhasil maka terdapat keterangan link errors : 0

5. Kini Anda telah memiliki file Latihan.HEX dan siap untuk disimulasikan dengan program utility AVSIM51 versi 1.30. Jalankan file program AVSIM51.EXE, selanjutnya pada menubar pilih Load $\rightarrow$

Bagaimana menggunakan Program AVSIM51 Versi 1.30 untuk 35 Simulasi Mikrokontroller 8031 (Andi Susilo) 
Program Enter, isikan nama file Latihan.HEX pada perintah berikut Enter filename : C:\AVSIM51lLatihan.HEX (Enter). Perhatikan tampilan dari program untuk bagian Label dan Operation, alamat offset awal akan ditunjukkan oleh simbol PC:0000 dengan Operation yang akan dilaksanakan adalah perintah LJMP 0030H

6. Eksekusi program setiap opcode dengan menekan F10, program awal berada pada alamat 30H ditunjukkan oleh label PC:0030.

Jika ingin mengeksekusi seluruh program tekan F1. Untuk memilih kecepatan eksekusi tekan F5 dengan 3 pilihan kecepatan yaitu Low, Mid dan High. Amati dengan teliti perubahan isi dari register-register DP (DPTR), R0 sampai R7, Data Space, P1 sampai P3 dan register A (Accumulator) menurut perintah mnemonic dari register yang bersesuaian. Jika setelah mengeksekusi baris perintah MOVX @DPTR,A muncul pesan:

"Trap: Undefined address: X: E003H", hal ini disebabkan program mengakses alamat peralatan eksternal, misalnya sebagai contoh adalah PPI8255 yang digunakan disini, pesan tersebut bukan menunjukkan kesalahan dalam membuat program, tetapi lokasi alamat yang tidak terdefinisi. Lanjutkan eksekusi pada baris program berikutnya.

7. Menu Expression digunakan untuk pindah dari suatu alamat baris program ke alamat baris program tujuan, misalnya jika sekarang posisi baris program berada di alamat 0034H (ditunjukkan dengan cahaya kotak terang), maka untuk mengeksekusi program pada alamat 0042H, pertama pindahkan dulu posisi baris program agar berada di alamat $0042 \mathrm{H}$, caranya pilih Expression pada menubar dan dari

36 Majalah Ilmiah Informatika, Vol. 4, No. 13, Desember 2002, Hal. 17-77 
perintah "Enter expression :" masukkan lokasi alamat tujuan 0042H, hasilnya sekarang cahaya kotak terang berada pada baris program alamat tersebut, untuk mengeksekusinya cukup tekan F10.

\section{Manajemen Memori}

Bagian ini menjelaskan bagaimana menghapus, mengisi, mengubah dan memindahkan isi dari memori.

1. Ketika program Latihan.HEX telah dieksekusi seluruhnya, terlihat sejumlah data di lokasi alamat Bank 2 : 10H-17H, misalnya alamat $0010 \mathrm{H}$ berisi $23 \mathrm{H}$, alamat $0011 \mathrm{H}$ berisi $24 \mathrm{H}$ dan seterusnya. Sekarang ubahlah data pada alamat $0010 \mathrm{H}$ dengan $49 \mathrm{H}$, caranya pilih dari menubar Memory $\rightarrow$ Fill tekan Enter dan isilah data untuk beberapa pertanyaan yang sesuai.

Lower Address : 0010H

Upper Address : 0010H

Enter Expression : 49H

Hasilnya alamat $0010 \mathrm{H}$ sekarang berisi data $49 \mathrm{H}$, untuk mengisikan data sejumlah alamat dari $0010 \mathrm{H}-0014 \mathrm{H}$ dengan nilai $50 \mathrm{H}$, maka lengkapi pertanyaan berikut :

Lower Address : $0010 \mathrm{H}$

Upper Address : 0014H

Enter Expression : 50H

Hasilnya alamat $0010 \mathrm{H}-0014 \mathrm{H}$ berisi data $50 \mathrm{H}$

2. Memindahkan data dari suatu alamat ke alamat tujuan, gunakan perintah pada menubar dengan cara Memory $\rightarrow$ Move tekan Enter, 
misalnya akan memindahkan data 24H di lokasi alamat 0011H ke alamat tujuan 0019H, lengkapi pertanyaan berikut :

Lower Address : 0011H

Upper Address : 0011H

Destination Address : 0019H

Perhatikan sekarang alamat $0019 \mathrm{H}$ berisi data $24 \mathrm{H}$ dan alamat $0011 \mathrm{H}$ juga tetap berisi data $24 \mathrm{H}$

3. Sekarang untuk mengosongkan lokasi alamat 0010H-0019H, gunakan perintah dari menubar Memory $\rightarrow$ Clear dan lengkapi pertanyaan berikut:

Lower Address : $10 \mathrm{H}$

Upper Address : $19 \mathrm{H}$

Hasilnya lokasi alamat $0010 \mathrm{H}-0019 \mathrm{H}$ berisi data $00 \mathrm{H}$

4. Perintah Search digunakan untuk mencari data pada alamat yang ditentukan, caranya pilih dari menubar Memory $\rightarrow$ Search dan tekan Enter. Misalnya, ingin mencari suatu data $33 \mathrm{H}$ di lokasi alamat 0018H, caranya lengkapi pertanyaan berikut:

Lower Address : $18 \mathrm{H}$

Upper Address : $18 \mathrm{H}$

Enter Search Expression : $33 \mathrm{H}$

Alamat 0018H termasuk dalam lokasi Bank 3, jika data 33H terdapat pada alamat tersebut maka akan ditampilkan pesan "Found at R0l". Jika data tidak terdapat pada alamat tersebut tetapi misalnya ditemukan pada alamat $001 \mathrm{AH}$, pesan yang ditampilkan "Found at R2l". Pesan menampilkan "Not found", jika tidak terdapat satu alamat pun berisi data $33 \mathrm{H}$. untuk mencari data pada alamat berikutnya

38 Majalah Ilmiah Informatika, Vol. 4, No. 13, Desember 2002, Hal. 17-77 
cukup dengan memilih dari menubar Memory $\rightarrow$ searchNext dan tekan Enter (atau untuk memudahkan cukup menekan huruf kapital M $\rightarrow \mathrm{N})$.

\section{Menampilkan isi memori (Dump Memory)}

Pada program AVSIM51, ruang data (data Space) yang dapat ditampilkan secara langsung adalah sebesar 64 bytes, ruang data ini dibagi menjadi 2 area yang masing-masing berkapasitas 32 bytes. Kondisi awal program AVSIM51 pertama kali dijalankan menampilkan ruang area 1 (Upper Dump Window) dengan 32 bytes data di lokasi alamat antara 0000H-001FH dan area 2 (Lower Dump Window) dengan 32 bytes data di lokasi alamat antara 0020H-003FH. Terdapat dua cara untuk menampilkan isi memori yaitu secara Absolute dan Indirect, secara Absolute menampilkan data dari lokasi alamat awal sebanyak 32 bytes pada area yang telah didefinisikan, kita hanya memasukkan lokasi memori absolute sebagai alamat awal program. Secara Indirect berarti menampilkan isi memori dengan penentuan alamat tidak langsung (Indirect Address) atau register dan nilainya dijumlahkan dengan Index Offset yang merupakan pergeseran (Displacement) alamat memori. Terdapat dua kemungkinan data yang ditampilkan.

- Lokasi data $=$ data dari lokasi alamat tidak langsung + Index Offset

- $\quad$ Lokasi data $=$ Isi dari register + Index Offset

Jadi lokasi data yang ditampilkan, tergantung apakah akan memilih melalui alamat tak langsung (Indirect Address) atau register. Agar lebih

Bagaimana menggunakan Program AVSIM51 Versi 1.30 untuk 39 Simulasi Mikrokontroller 8031 (Andi Susilo) 
jelas penulis memberikan masing-masing contoh secara Absolute dan Indirect untuk menampilkan data.

1. Menampilkan data pada lokasi alamat secara Absolute, misalnya kita ingin melihat data melalui area 1 dengan alamat awal $0045 \mathrm{H}$, dari menubar pilih Dump $\rightarrow 1 \rightarrow$ Absolute dan tekan Enter, tuliskan alamat awal dari pertanyaan berikut :

Enter Expression in data Address Space : $45 \mathrm{H}$

Maka akan ditampilkan data dari alamat awal $0045 \mathrm{H}$ pada area 1 sebanyak 32 bytes, berlatihlah untuk menampilkan data melalui alamat Absolute yang lain.

2. Menampilkan data pada lokasi alamat secara Indirect, perhatikan contoh berikut, pilih dari menubar Dump $\rightarrow 1 \rightarrow$ Indirect (Enter, masukkan lokasi alamat tak langsung $0020 \mathrm{H}$ pada pertanyaan:

Enter Expression in Data Address Space: $20 \mathrm{H}$

Kemudian isikan untuk Index Offset dengan nilai 08H:

Enter Expression in Data Address Space: 08H

Index Offset

Misalnya data dari lokasi alamat tak langsung 0020H: 00H dengan Index Offset: $08 \mathrm{H}$ berarti operasi ini akan menampilkan data dilokasi $00 \mathrm{H}+08 \mathrm{H}=0008 \mathrm{H}$, keterangan yang ditampilkan pada program “@D:0020H+R0” in Data Space “, R0’ menunjukkan data berada di lokasi Bank 1 dengan alamat awal 0008H. Sekarang perhatikan contoh kedua berikut ini.

- Pilih menubar eXecute dan tuliskan mnemonic MOV R0,\#08H Nilai data yang ditampilkan pada alamat 0000H: 08H (Bank 0)

- Pilih dari menubar Dump $\rightarrow 1 \rightarrow$ Indirect tekan Enter

40 Majalah Ilmiah Informatika, Vol. 4, No. 13, Desember 2002, Hal. 17-77 
Isikan alamat tak langsung (Indirect Address) dengan $00 \mathrm{H}$

Isikan Index Offset dengan $02 \mathrm{H}$

Hasilnya menampilkan data pada lokasi alamat 000AH dengan nilai $00 \mathrm{H}$.

Cara kerjanya data dari lokasi Indirect Address $08 \mathrm{H}$ dijumlahkan dengan Index Offset $02 \mathrm{H}$ menghasilkan $0008 \mathrm{H}+$ $0002 \mathrm{H}=000 \mathrm{AH}$, alamat ini berisi data $00 \mathrm{H}$, keterangan yang ditampilkan program “@R0 + R2 in Data Space”, alamat register $\mathrm{R} 0=0000 \mathrm{H}$ dan alamat register $\mathrm{R} 2=0002 \mathrm{H}($ Bank 0$)$

- Perhatikan contoh berikut ini, Pilih dari menubar Dump $\rightarrow 2 \rightarrow$ Indirect tekan Enter

Tuliskan register R0 pada pertanyaan :

Enter Expression in Data Address Space :

Tuliskan Index Offset 02H pada pertanyaan :

Enter Expression in Data Address Space :

Index Offset

Hasilnya sama dengan contoh diatas tetapi menampilkan data pada area 2 lokasi alamat 000AH dengan nilai $00 \mathrm{H}$.

Keterangan yang ditampilkan program “@R0 + R2 in Data Space"

- Perhatikan kembali contoh terakhir ini. Pilih dari menubar Dump $\rightarrow 2 \rightarrow$ Indirect tekan Enter. Tuliskan register P1 pada pertanyaan :

Enter Expression in Data Address Space : 
Tuliskan Index Offset $03 \mathrm{H}$ pada pertanyaan :

Enter Expression in Data Address Space : Index Offset

Hasilnya menampilkan data pada area 2 di lokasi alamat yang ditunjukkan oleh register P1(Port 1) 00FFH dijumlahkan dengan Index Offset 03H (alamat register R3 Bank 0) yaitu $00 \mathrm{FFH}+0003 \mathrm{H}=0003 \mathrm{H}(00 \mathrm{FFH}$ adalah alamat tertinggi untuk Memori Data)

Keterangan yang ditampilkan program “@ @ $1+\mathrm{R} 3$ in data Space"

Cobalah Anda berlatih menampilkan data pada suatu lokasi alamat dengan nilai Register, Indirect Address dan Index Offset yang berbeda-beda.

\section{Mengganti atau mengisi Opcode pada satu atau lebih baris program}

1. Jalankan program AVSIM51.EXE

2. Dari menubar pilih Load $\rightarrow$ Program dan tekan Enter

3. Tuliskan file Latihan.HEX menurut direktori yang telah dibuat pada pertanyaan

Enter Filename : C:\AVSIM51\Latihan.HEX tekan Enter

4. Eksekusi program perbaris dengan menekan F10, sampai posisi pada alamat yang diperlihatkan (cahaya kotak terang) di bagian Label dan Operation seperti berikut ini :

LABEL OPERATION

0033H MOV DPTR,\#E003H

42 Majalah Ilmiah Informatika, Vol. 4, No. 13, Desember 2002, Hal. 17-77 
memperlihatkan alamat untuk Control Word PPI8255, sekarang kita akan mengganti alamat Control Word E003H dengan FF13H.

Pilih dari menubar Patch $\rightarrow$ Patch code tekan Enter dan masukkan mnemonicnya

Enter mnemonic : MOV DPTR,\#FF13H

PATCH Code at PC

Hasilnya akan terlihat alamat E003H diganti dengan FF13H.

Gantilah mnemonic MOV A,\#80H dengan MOV A,\#82H yang berada di lokasi alamat $0036 \mathrm{H}$.

5. Jika ingin mengganti program pada alamat tertentu, maka pindahkan dulu penunjuk posisi (Cahaya kotak terang) ke posisi alamat program/mnemonic yang ingin diganti, caranya dari menubar pilih Expression tekan Enter, pada perintah :

Enter Expression :

Expression will be stored at PC

Isikan dengan lokasi alamat dari posisi mnemonic yang akan diganti.

Contoh :

Jika ingin mengganti mnemonic MOV PSW,\#10H yang berada di lokasi alamat $0030 \mathrm{H}$ menjadi mnemonic MOV PSW,\#18H.

Dari menubar pilih Expression tekan Enter, masukkan lokasi alamat $30 \mathrm{H}$ pada perintah Enter Expression: 30H, hasilnya sekarang penunjuk posisi (Cahaya kotak terang) berada di lokasi alamat $0030 \mathrm{H}$, untuk mengganti mnemonic dari menubar pilih Patch $\rightarrow$ Patch code tekan Enter, selanjutnya masukkan mnemonic pada perintah :

Bagaimana menggunakan Program AVSIM51 Versi 1.30 untuk 43 Simulasi Mikrokontroller 8031 (Andi Susilo) 
Enter mnemonic : MOV PSW,\#18H

Expression will be stored at PC

Bisa juga mengganti mnemonic dengan cara yang lebih cepat, tekan <CNGMDE > Esc untuk melakukan operasi toggle pada modus display, mengubah nilai dari PC (memilih PC dengan kunci ekspress tekan Ctrl-P) dengan 0030H, selanjutnya pilih perintah Patch $\rightarrow$ Patch code tekan Enter. Proses selanjutnya sama dengan diatas. Untuk menjalankan program Dri ppermulaan, setelah merubah mnemonic maka laksanakan proses reset CPU dengan perintah reset $\rightarrow \mathrm{CPU}$ (atau tekan $\mathrm{R} \rightarrow \mathrm{C}$ )

Penunjuk posisi akan berada pada alamat awal program, kemudian eksekusi program dengan menekan F10. Perhatikan bahwa beberapa mnemonic pada lokasi alamat $0033 \mathrm{H}$ dan $0036 \mathrm{H}$ telah diganti.

44 Majalah Ilmiah Informatika, Vol. 4, No. 13, Desember 2002, Hal. 17-77 


\section{File Perintah (Command File)}

Sebuah Command file berisi serangkaian perintah-perintah AVSIM51. Saat menciptakan sebuah command file, AVSIM51 membuka sebuah file. Seluruh keypress disimpan di dalam file sampai Anda menutupnya. Ketika mengeksekusi file, AVSIM51 menafsirkan masingmasing keypress di dalam file, meskipun telah diketikan langsung di terminal. File-file perintah paling berguna dalam pengaturan sebuah lingkungan standar atau serangkaian breakpoints, tetapi file-file tersebut dapat digunakan kapanpun saat harus memasukkan serangkaian keystrokes. File-file perintah mungkin diturunkan dari tingkat kelima. Menu commandFile dtampilkan sebagai berikut :

COMMAND FILE: Load SAVE: Open Close Restart

\section{$10.1 \mathrm{Load}$}

Load membaca sebuah file perintah yang disimpan sebelumnya dan mengeksekusi perintah. Ketika diberikan perintah Load, AVSIM51 akan meminta untuk memasukkan nama file. Masukkan nama file termasuk nama drive dan path jika diperlukan.

AVSIM51 akan membuka file dan mengeksekusi perintahperintah di dalamnya. Anda akan melihat perintah-perintah dan pesanpesan yang diperlihatkan dengan kecepatan tinggi sampai AVSIM51 mencapai akhir file (EOF).

Contoh:

Pilih dari menubar commandFile $\rightarrow$ Load dan tekan Enter Enter filename : comfile.sav tekan Enter

Bagaimana menggunakan Program AVSIM51 Versi 1.30 untuk 45 Simulasi Mikrokontroller 8031 (Andi Susilo) 
File perintah "comfile.sav" dibuka dan dieksekusi. Ini adalah sebuah perintah berguna, untuk memberikan pilihan baris perintah ketika pertama kali menjalankan AVSIM51.

\subsection{Open}

Perintah Open membuka file perintah yang dispesifikasikan dan mulai menyimpan keystrokes. Ketika memilih Open, AVSIM51 akan meminta untuk diisikan nama file. Masukkan nama file, termasuk drive dan path file tersebut berada dan tekan Enter.

Jika terdapat file perintah lain yang sedang terbuka, AVSIM51 akan menutupnya sebelum menciptakan file yang dispesifikasikan. Jika sebuah file perintah dengan nama yang sama telah dimiliki di dalam direktori yang ditentukan, maka file tersebut akan dihapus.

Contoh:

Pilih dari menubar commandFile $\rightarrow$ Open dan tekan Enter

Enter filename : comfile.sav (Enter)

File perintah "comfile.sav" dibuka, seluruh keystrokes, dimulai dan berikutnya akan disimpan di dalam file "comfile.sav" sampai file tersebut ditutup.

\subsection{Close}

Perintah Close akan menutup file perintah yang terbuka, jika memang terdapat satu file perintah yang terbuka.

Contoh :

Jika file perintah "comfile.sav" sedang terbuka.

Maka saat dilaksanakan perintah commandFile $\rightarrow$ Close maka file perintah "comfile.sav" akan ditutup.

46 Majalah Ilmiah Informatika, Vol. 4, No. 13, Desember 2002, Hal. 17-77 


\subsection{Restart}

Perintah Restart akan menutup file perintah, jika terdapat satu file perintah yang terbuka, kemudian membuka ulang file perintah tersebut, menghapus keystrokes apapun di dalam file. Perintah ini berguna ketika membuat sebuah kesalahan dan ingin menghapus file yang lama dan memulai kembali.

Contoh :

Jika file perintah "comfile.sav" terbuka,

Dan mengerjakan perintah commandFile $\rightarrow$ Restart tekan Enter, maka versi lama dari file perintah "comfile.sav" akan dihapus dan file versi baru dibuka.

file perintah bisa diedit dengan editor teks, tetapi akan menjadi sulit, terutama jika terdapat beberapa kunci kontrol yang direkam di dalam file, tetapi akan dieksekusi di waktu file perintah dijalankan.

\subsection{Cara membuat file perintah (Command File).}

Mungkin terdapat suatu pertanyaan bagaimanakah cara membuat file perintah agar dapat dieksekusi dan melihat hasilnya sesuai keinginan pengguna. Penulis telah mencoba dan berhasil membuat file perintah sederhana dengan nama file yang sama yaitu comfile.sav. Perintah yang akan disimpan di file ini adalah menampilkan data pada alamat area 1 secara tak langsung (Indirect), alamat tak langsung bernilai 31H dan Index offset bernilai $31 \mathrm{H}$, setelah itu program akan mereset CPU. Cara membuat file dijelaskan berikut ini :

Bagaimana menggunakan Program AVSIM51 Versi 1.30 untuk 
1. Membuka program editor teks Notepad di dalam windows 95 .

2. Menuliskan serangkaian perintah berikut di dalam halaman teks :

D1I31H

$31 \mathrm{H}$

$\mathrm{RC}$

3. Menyimpan file dengan nama comfile.asm pada drive dan direktori C:lavsim51, setelah itu ganti nama file comfile.asm menjadi file perintah C:lavsim51\comfile.sav.

4. Kode D1I31H

\section{$31 \mathrm{H}$}

berarti sama dengan melaksanakan perintah Dump $\rightarrow 1 \rightarrow$ Indirect

Mengisi alamat tak langsung (Indirect Address) dengan $31 \mathrm{H}$ dan mengisi index offset dengan $31 \mathrm{H}$.

Kode RC

Berarti, melaksanakan perintah Reset $\rightarrow \mathrm{Cpu}$

5. Untuk menjalankan file perintah comfile.sav, pilih commandFile $\rightarrow$

Load (Enter). Setelah itu, masukkan nama file yang akan dibuka pada drive dan direktori yang dispesifikasikan C:lavsim51lcomfile.sav (Enter).

File perintah akan dibuka dan dieksekusi. Lihatlah hasil eksekusi file perintah yang telah dibuat.

6. Untuk menutup file perintah comfile.sav, pilih commandFile $\rightarrow$ Close dan tekan Enter (atau cukup menekan huruf kapital FC). Maka file perintah akan ditutup.

48 Majalah Ilmiah Informatika, Vol. 4, No. 13, Desember 2002, Hal. 17-77 
XI. Tabel Kunci Fungsi, Kontrol Kursor Dasar, Kunci Pengeditan dan Kunci Ekspress.

\subsection{Tabel Kunci Fungsi}

\begin{tabular}{|c|c|c|}
\hline Nama Kunci & Kunci IBM-PC & Deskripsi Kunci \\
\hline$<\mathrm{GO}>$ & $\mathrm{F} 1$ & $\begin{array}{l}\text { Memulai dan menghentikan simulasi yang } \\
\text { berlangsung dari CPU target. }\end{array}$ \\
\hline$<B K U P>$ & F2 & $\begin{array}{l}\text { Menggerakkan kursor breakpoint ke atas satu } \\
\text { opcode didalam fragmen program. }\end{array}$ \\
\hline$<\mathrm{BKST}>$ & F3 & $\begin{array}{l}\text { Mengatur sebuah breakpoint dinamik R/W } \\
\text { pada kursor lokasi breakpoint, kemudian } \\
\text { mengatur kursor lokasi breakpoint ke nilai PC. }\end{array}$ \\
\hline$<\mathrm{BKDN}>$ & $\mathrm{F} 4$ & $\begin{array}{l}\text { Menggerakkan kursor breakpoint kebawah } \\
\text { satu opcode di dalam fragmen program. }\end{array}$ \\
\hline$<$ SPD $>$ & F5 & $\begin{array}{l}\text { Memilih kecepatan (HI atau MEDium atau } \\
\text { LOW) dari simulasi yang sedang berjalan. }\end{array}$ \\
\hline$<\mathrm{DSP}>$ & F6 & $\begin{array}{l}\text { Memulai atau menghentikan pengubahan } \\
\text { display yang berlangsung, menghentikan } \\
\text { pengubahan untuk menaikkan kecepatan } \\
\text { simulasi atau memulainya untuk melihat hasil } \\
\text { dari masing-masing opcode pada chip target. }\end{array}$ \\
\hline$<$ WMOD> & F7 & $\begin{array}{l}\text { Mengatur jenis window (BINary, HEX, atau } \\
\text { ASCII). Kursor akan bergerak jika window } \\
\text { dapat menampilkan data lebih dari satu radix. }\end{array}$ \\
\hline$<\mathrm{SKP}>$ & F8 & $\begin{array}{l}\text { Melaksanakan toggle subrutin switch skip ON } \\
\text { dan OFF. Di dalam modus single-step, ketika } \\
\text { switch ON, simulator tidak akan }\end{array}$ \\
\hline
\end{tabular}

Bagaimana menggunakan Program AVSIM51 Versi 1.30 untuk 49 Simulasi Mikrokontroller 8031 (Andi Susilo) 


\begin{tabular}{|c|c|l|}
\hline & & $\begin{array}{l}\text { melaksanakan operasi single-step melalui } \\
\text { subrutin, ketika switch OFF, simulator akan } \\
\text { melaksanakan operasi single-step melalui } \\
\text { subrutin. }\end{array}$ \\
\hline$<$ UNDO> & F9 & $\begin{array}{l}\text { Operasi Undo satu opcode. Mengembalikan } \\
\text { seluruh memori, register, file I/O dan counter } \\
\text { siklus yang lewat ke kondisi sebelumnya. } \\
\text { Counter passpoint tidak dilakukan dengan } \\
\text { kunci ini. Perintah Undo akan mengembalikan } \\
\text { seluruh perintah Reset CPU, Execute dan } \\
\text { interupsi. }\end{array}$ \\
\hline$<$ SSTEP> & F10 & $\begin{array}{l}\text { Melewati melalui program satu opcode setiap } \\
\text { kunci ditekan. Mengabaikan seluruh } \\
\text { breakpoint. }\end{array}$ \\
\hline$<$ TRACE> & Alt-F6 & $\begin{array}{l}\text { Melaksanakan toggle pengubahan window } \\
\text { secara individu ON dan OFF, jika OFF display } \\
\text { akan diteruskan. }\end{array}$ \\
\hline$<$ SCLTOG $>$ & PgUp & $\begin{array}{l}\text { Melaksanakan toggle Modus Scroll ON dan } \\
\text { OFF. Ketika Modus Scroll OFF (default), kunci } \\
\text { kursor bergerak bebas sekitar keyboard. } \\
\text { Ketika Modus Scroll ON, kursor akan dibatasi } \\
\text { dalam satu window. }\end{array}$ \\
\hline
\end{tabular}

50 Majalah Ilmiah Informatika, Vol. 4, No. 13, Desember 2002, Hal. 17-77 


\subsection{Tabel Kontrol Kursor Dasar}

\begin{tabular}{|c|c|c|}
\hline Nama Kunci & Kunci IBM-PC & Fungsi \\
\hline$\leftarrow$ & Keypad 4 & $\begin{array}{l}\text { Menggerakkan kursor satu } \\
\text { karakter ke kiri. }\end{array}$ \\
\hline$\rightarrow$ & Keypad 6 & $\begin{array}{l}\text { Menggerekkan kursor satu } \\
\text { karakter ke kanan. }\end{array}$ \\
\hline$\uparrow$ & Keypad 8 & $\begin{array}{l}\text { Menggerakkan kursor ke } \\
\text { atas satu baris. }\end{array}$ \\
\hline$\downarrow$ & Keypad 2 & $\begin{array}{l}\text { Menggerakkan kursor ke } \\
\text { bawah satu baris. }\end{array}$ \\
\hline Home & Keypad 7 & $\begin{array}{l}\text { Menggerakkan kursor ke } \\
\text { karakter pertama dari } \\
\text { window. }\end{array}$ \\
\hline End & Keypad 1 & $\begin{array}{l}\text { Menggerakkan kursor ke } \\
\text { karakter terakhir dari } \\
\text { window. }\end{array}$ \\
\hline PgUp & Keypad 9 & $\begin{array}{l}\text { Di dalam area dump } \\
\text { memori, menggulung ke } \\
\text { atas data penting satu } \\
\text { window. Di dalam PC, } \\
\text { menggulung maju kode } \\
\text { penting ( } 20 \text { baris). }\end{array}$ \\
\hline PgDn & Keypad 3 & $\begin{array}{l}\text { Di dalam area dump } \\
\text { memori, menggulung ke } \\
\text { bawah data penting satu } \\
\text { window. Di dalam PC, } \\
\text { menggulung mundur kode } \\
\text { penting ( } 20 \text { baris). }\end{array}$ \\
\hline
\end{tabular}

Bagaimana menggunakan Program AVSIM51 Versi 1.30 untuk 51 Simulasi Mikrokontroller 8031 (Andi Susilo) 


\subsection{Kunci Pengeditan}

\begin{tabular}{|l|l|l|}
\hline Nama Kunci & Kunci IBM-PC & Deskripsi \\
\hline Increment & + & $\begin{array}{l}\text { Menambahkan satu ke sebuah } \\
\text { alamat byte atau word. } \\
\text { Melaksanakan toggle sebuah } \\
\text { bit.Di dalam PC, melanjutkan } \\
\text { ke opcode berikutnya. }\end{array}$ \\
\hline Decrement & - & $\begin{array}{l}\text { Mengurangkan satu ke sebuah } \\
\text { alamat byte atau word. } \\
\text { Melaksanakan toggle sebuah } \\
\text { bit.Di dalam PC, melanjutkan } \\
\text { ke opcode sebelumnya. }\end{array}$ \\
\hline Clear to End & Ctrl-End & $\begin{array}{l}\text { Mereset (Clear) seluruh byte } \\
\text { dari posisi kursor ke akhir } \\
\text { window. Nilai Heksadesimal } \\
\text { dan biner diatur ke nol. Nilai } \\
\text { ASCII diatur ke spasi (20H) }\end{array}$ \\
\hline Clear-Window & Ctrl-Home & $\begin{array}{l}\text { Mereset window, mengatur } \\
\text { window-window heksadesimal } \\
\text { dan biner ke nol, dan window- } \\
\text { window ASCII ke spasi (20H) }\end{array}$ \\
\hline Toggle & & $\begin{array}{l}\text { Melaksanakan toggle byte dari } \\
\text { bit/nibble atau ASCII di bawah } \\
\text { kursor ke komplemen 1 }\end{array}$ \\
\hline
\end{tabular}

52 Majalah Ilmiah Informatika, Vol. 4, No. 13, Desember 2002, Hal. 17-77 


\subsection{Kunci Ekspress}

\begin{tabular}{|l|l|}
\hline Kunci IBM-PC & Deskripsi \\
\hline Return & Berada di akhir window \\
\hline Ctrl - $\rightarrow$ & Window berikutnya ke kanan \\
\hline Ctrl - $\leftarrow$ & Window sebelumnya ke kiri \\
\hline Ctrl - A & Accumulator \\
\hline Ctrl - P & Program Counter \\
\hline Ctrl - S & Stack Pointer \\
\hline Ctrl - R & Register Bank \\
\hline Alt - 0 sampai 7 & Register R0 sampai R7 \\
\hline Ctrl - D & Data Pointer \\
\hline Ctrl - C & Carry Flag \\
\hline Ctrl - X & Auxiliary Carry Flag \\
\hline Ctrl - F & User Flag \\
\hline Ctrl - O & Overflow Flag \\
\hline Ctrl - B & Register B \\
\hline Ctrl - I & Interrupt Enable Flag \\
\hline Ctrl - T & Timer 0 \\
\hline Alt - A & Memory Dump Area 1 \\
\hline Alt - B & Memory Dump Area 2 \\
\hline Alt - P & Port 0 (Port 1 pada 8031/8032) \\
\hline Alt - Q & Port 2 (Port 3 pada 8031/8032) \\
\hline Alt - C & Serial Port Receive Buffer \\
\hline Alt - S & Serial Port Control Register \\
\hline Alt - Y & Cycles Register \\
\hline & \\
\hline
\end{tabular}

Bagaimana menggunakan Program AVSIM51 Versi 1.30 untuk 
XII. Mempelajari Perangkat Keras 8031 melalui Sintaks Bahasa Assembler Instruksi 8051

Sejauh ini kita telah mempelajari bagaimana menggunakan program bantu AVSIM51 untuk simulasi operasi dari mikrokontroler 8031, akan lebih baik bereksperimen secara langsung dengan perintahperintah yang terdapat dari menu utama seperti Memory, Patch, commandFile, I/O, Reset, Dump, Load dan seterusnya. Memahami maksudnya, mempelajari bagian-bagian penting dan mudah dahulu, sehingga dapat segera membuat program untuk mikrokontroler 8031/8032 proyek sendiri dan mensimulasikannya dengan AVSIM51.

Saran penulis, kerjakan program-program latihan yang terdapat dalam bagian ini secara bertahap dan amati cara kerja setiap instruksi (opcode), kerjakan juga bagaimana membuat file-file tertentu yang diperlukan seperti File Perintah, File Patch, File I/O. Secara bertahap sehingga nanti akan lebih mengerti maksud dan tujuan perintah-perintah atau fungsi-fungsi tertentu tersebut yang sebelumnya mungkin sulit dipahami.

\subsection{Perangkat instruksi operasi aritmatika dan subrutin.}

Program Latihan.ASM yang telah diujikan pada bagian terdahulu, memberikan pengetahuan instruksi dasar penentuan konstanta, penentuan alamat awal, lompatan tidak terkondisi (Unconditional Jump) melalui perintah JMP, modus pengalamatan, mengakses alamat memori dan penggunaan beberapa register fungsi khusus dan serbaguna.

Sekarang waktunya untuk mempelajari lebih banyak mnemonik dari perangkat instruksi Mikrokontroler 8031, terutama instruksi-instruksi

54 Majalah Ilmiah Informatika, Vol. 4, No. 13, Desember 2002, Hal. 17-77 
operasi aritmatika seperti penjumlahan, pengurangan, perkalian, pembagian dan juga operasi logika, penggunaan lompatan terkondisi (Conditional Jump), pembuatan subrutin atau prosedur dan manipulasi bit, kemudian jalankan program secara single-step. Bersamaan dengan menuliskan program, pelajari fungsi instruksi tersebut melalui bagian komentar yang disertakan. Ketika menjalankannya secara single-step, cobalah perkirakan hasil eksekusi yang terjadi terhadap isi register, alamat memori dan seterusnya yang terkait dan bandingkan dengan hasil simulasi dari program AVSIM51, jika hasilnya sesuai berarti fungsi instruksi tersebut telah dipahami, tetapi jika hasilnya berbeda, carilah sebab perbedaannya dan letak kesalahannya. Tuliskan program Latihan2.ASM berikut ini, menggunakan teks editor:

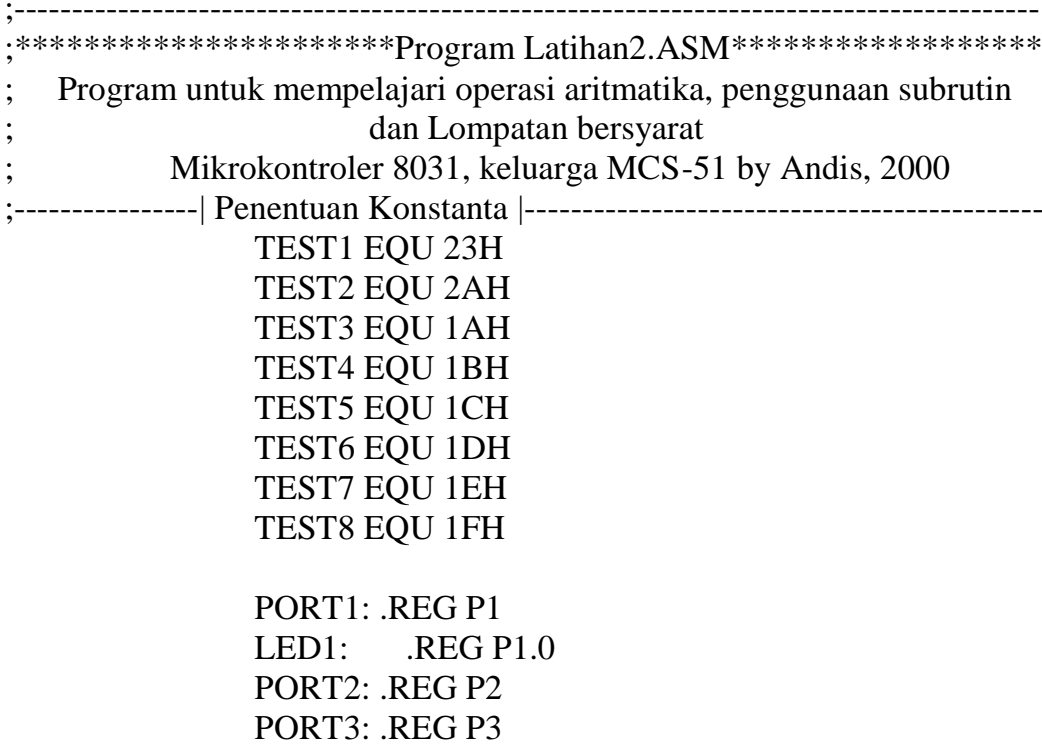

Bagaimana menggunakan Program AVSIM51 Versi 1.30 untuk 55 Simulasi Mikrokontroller 8031 (Andi Susilo) 


\begin{tabular}{|c|c|c|}
\hline \multirow{7}{*}{ MULAI: } & \multirow{2}{*}{\multicolumn{2}{|c|}{ ORG $00 \mathrm{H}$; alamat awal perintah JMP MULAI }} \\
\hline & & \\
\hline & \multicolumn{2}{|c|}{ JMP MULAI $\quad ;$ Menuju label MULAI } \\
\hline & \multicolumn{2}{|c|}{ ORG 40H $\quad$; Lokasi alamat awal program } \\
\hline & \multicolumn{2}{|c|}{$\begin{array}{c}\text { MOV PSW,\#10H; Program Status Word, lokasi } \\
\text {; alamat Bank } 2\end{array}$} \\
\hline & \multirow{2}{*}{$\begin{array}{l}\text { MOV PORT1,\#00H } \\
\text { SETB LED1 }\end{array}$} & ; Kirim data $00 \mathrm{H}$ ke P1 \\
\hline & & $\begin{array}{l}\text {; Aktifkan Port P1 untuk } \\
\text {; bit P1.0 }\end{array}$ \\
\hline & \multirow{2}{*}{$\begin{array}{l}\text { MOV PORT3,\#44H } \\
\text { MOV R0,\#TEST1 }\end{array}$} & ; Kirim data $44 \mathrm{H}$ ke P3 \\
\hline & & $\begin{array}{l}\text {; Register R0 berisi konstanta } \\
\text {; label TEST1 }\end{array}$ \\
\hline & MOV R1,\#TEST2 & $\begin{array}{l}\text {; Register R1 berisi konstanta } \\
\text {; label TEST2 }\end{array}$ \\
\hline & MOV R2,\#TEST3 & $\begin{array}{l}\text {; Register R2 berisi konstanta } \\
\text {; label TEST3 }\end{array}$ \\
\hline & CJNE R1,\#2BH,PIN1 & $\begin{array}{l}\text {; Jika R1 }<>2 \text { BH menuju } \\
\text {; label PIN1 }\end{array}$ \\
\hline \multirow[t]{6}{*}{ PIN4: } & MOV R3,\#TEST4 & $\begin{array}{l}\text {; Register R3 berisi konstanta } \\
\text {; label TEST4 }\end{array}$ \\
\hline & MOV R4,\#TEST5 & $\begin{array}{l}\text {; Register R4 berisi konstanta } \\
\text {; label TEST5 }\end{array}$ \\
\hline & MOV R5,\#TEST6 & $\begin{array}{l}\text {; Register R5 berisi konstanta } \\
\text {; label TEST6 }\end{array}$ \\
\hline & \multirow{2}{*}{$\begin{array}{l}\text { CALL TUNDA } \\
\text { MOV R6,\#TEST7 }\end{array}$} & ; Menuju subrutin TUNDA \\
\hline & & $\begin{array}{l}\text {; Register R6 berisi konstanta } \\
\text {; label TEST7 }\end{array}$ \\
\hline & MOV R7,\#TEST8 & $\begin{array}{l}\text {; Register R7 berisi konstanta } \\
\text {; label TEST8 }\end{array}$ \\
\hline
\end{tabular}

Operasi Aritmetika |

SETB C ; Set bit Carry Flag

ANL A,@R0 ; Register akumulator di-AND-kan

; dengan data yang lokasi alamatnya

; ditunjukkan oleh register R0

ADDC A,\#22H ; Akumulator ACC berisi C + A + 22H

CPL A ; Akumulator dikomplemenkan 1

ORL 13H,\#02H ; Data di lokasi alamat 13H di-OR-kan

56 Majalah Ilmiah Informatika, Vol. 4, No. 13, Desember 2002, Hal. 17-77 


\begin{tabular}{|c|c|c|}
\hline & & ; dengan $02 \mathrm{H}$ \\
\hline & MOV A,\#23H & ; Mengisi akumulator dengan $23 \mathrm{H}$ \\
\hline & MOV B,\#4H & ; Mengisi register B dengan 04H \\
\hline & PUSH B & $\begin{array}{l}\text {; Menaikkan satu register stack } \\
\text {; menyimpan data register B }\end{array}$ \\
\hline & MUL A, B & $\begin{array}{l}\text {; Mengalikan isi register akumulator } \\
\text {; dengan isi register pengali B }\end{array}$ \\
\hline & MOV B,\#2H & ; Mengisi register $\mathrm{B}$ dengan $02 \mathrm{H}$ \\
\hline & DIV A, B & $\begin{array}{l}\text {; Membagi isi register akumulator } \\
\text {; dengan isi register B }\end{array}$ \\
\hline & XRL A,A & $\begin{array}{l}\text {; Operasi XOR register akumulator } \\
\text {; dengan dirinya sendiri hasilnya } \\
\text { disimnan di register akumulator }\end{array}$ \\
\hline & POP B & $\begin{array}{l}\text {; Menurunkan posisi alamat stack } \\
\text {; pointer (SP) dengan satu, } \\
\text {; mengeluarkan isi dari register B }\end{array}$ \\
\hline & MOV@R0,\#41 & I; Mengisi data $41 \mathrm{H}$ pada lokasi alamat \\
\hline & MOV@R1,\#4CH & $\begin{array}{l}\text {; Mengisi data } 4 \mathrm{CH} \text { pada lokasi alamat } \\
\text {; yang ditunjukkan oleh register R1 }\end{array}$ \\
\hline & JMP ULANG & ; Melompat ke label ULANG \\
\hline PIN1: & MOV A,\#2BH & $\begin{array}{l}\text {; Mengisi akumulator dengan } \\
\text {; data } 2 \mathrm{BH}\end{array}$ \\
\hline & $\mathrm{ADD} \mathrm{A}, \# 4 \mathrm{H}$ & $\begin{array}{l}\text {; Menambahkan isi akumulator dengan } \\
\text {; 04H hasilnya disimpan di register } \\
\text {; akumulator }\end{array}$ \\
\hline & MOV R1,A & $\begin{array}{l}\text {; Mengisi register R1 dengan isi dari } \\
\text {; register A }\end{array}$ \\
\hline & PUSH R1 & $\begin{array}{l}\text {; Menaikkan isi register stack dengan } \\
\text {; satu dan menyimpan isi register R1, } \\
\text {; posisi awal stack standar 07H setelah } \\
\text {; dijalankan perintah PUSH menjadi } \\
\text {; } 08 \mathrm{H}\end{array}$ \\
\hline & SUBB A,\#3H & $\begin{array}{l}\text {; Mengurangkan isi akumulator } \\
\text {; dengan } 03 \mathrm{H} \text { hasilnya disimpan } \\
\text {; di register akumulator }\end{array}$ \\
\hline
\end{tabular}

Bagaimana menggunakan Program AVSIM51 Versi 1.30 untuk Simulasi Mikrokontroller 8031 (Andi Susilo) 


\begin{tabular}{|c|c|c|}
\hline \multicolumn{2}{|c|}{ POP R1 } & ; Mengurangkan isi register stack \\
\hline \multicolumn{2}{|c|}{ MOV R1,A } & $\begin{array}{l}\text {; Mengisi register R1 dengan isi } \\
\text {; dari akumulator }\end{array}$ \\
\hline \multicolumn{2}{|c|}{ JMP PIN2 } & ; Melompat menuju label PIN2 \\
\hline \multicolumn{2}{|c|}{ DEC R1 } & $\begin{array}{l}\text {; Mengurangkan isi register R1 } \\
\text {; dengan satu }\end{array}$ \\
\hline \multicolumn{2}{|c|}{ JMP PIN4 } & ; Melompat menuju label PIN4 \\
\hline \multirow[t]{2}{*}{ ULANG: } & NOP & ; Tidak ada operasi \\
\hline & SJMP ULANG & ; Menuju label ULANG \\
\hline \multirow[t]{4}{*}{ PIN2: } & DEC R1 & $\begin{array}{l}\text {; Mengurangkan isi register R1 } \\
\text {; dengan } 1\end{array}$ \\
\hline & XRL A,\#4H & $\begin{array}{l}\text {; Operasi XOR antara isi akumulator } \\
\text {; dengan } 04 \mathrm{H}\end{array}$ \\
\hline & SWAP A & $\begin{array}{l}\text {; Menukar isi nibble bawah (0-3) } \\
\text {; dengan isi nibble atas (4-7) dari }\end{array}$ \\
\hline & JMP PIN3 & $\begin{array}{l}\text {; register akumulator } \\
\text {; Menuju label PIN3 }\end{array}$ \\
\hline \multirow{5}{*}{$\begin{array}{l}\text { TUNDA: } \\
\text { DEL1: } \\
\text { DEL2: }\end{array}$} & MOV R5,\#3H & ; Mengisi register R5 dengan $03 \mathrm{H}$ \\
\hline & MOV R6,\#2H & ; Mengisi register R6 dengan $02 \mathrm{H}$ \\
\hline & DJNZ R6,DEL2 & $\begin{array}{l}\text {; Mengurangkan register R6 dengan } \\
\text {; satu, jika R6 }<>0 \text { menuju } \\
\text {; label DEL2 }\end{array}$ \\
\hline & DJNZ R5,DEL1 & $\begin{array}{l}\text {; Mengurangkan register R5 dengan } \\
\text {; satu, jika R5 }<0 \text { menuju } \\
\text {; label DEL1 }\end{array}$ \\
\hline & RET & $\begin{array}{l}\text {; Kembali ke baris program dari } \\
\text {; perintah CALL dan menjalankan } \\
\text {; opcode pada baris berikutnya }\end{array}$ \\
\hline
\end{tabular}

Setelah menuliskan seluruh program, simpan program dengan nama file latihan2.ASM. Perhatikan perintah CALL berarti memanggil

58 Majalah Ilmiah Informatika, Vol. 4, No. 13, Desember 2002, Hal. 17-77 
sebuah subrutin/prosedur yang diberikan label nama tertentu. CALL TUNDA berarti memanggil subrutin dengan nama TUNDA.

Subrutin merupakan program kecil, yang diperlukan ketika terdapat operasi dengan fungsi yang sama dilaksanakan lebih dari satu kali. Subrutin membuat program menjadi terstruktur, ringkas, mudah dalam analisa dan mempercepat waktu eksekusi. Subrutin selalu diakhiri dengan perintah RET, artinya setelah sebuah subrutin selesai dijalankan, perintah RET akan mengembalikan program menuju lokasi alamat perintah program berikutnya, tepat setelah perintah CALL subrutin. Program latihan berikutnya akan sering menjumpai Subrutin.

Untuk melaksanakan simulasi, ubahlah file Latihan2.ASM menjadi Latihan2.HEX agar dapat digunakan oleh Simulator AVSIM51. Berikut ini tahap untuk melaksanakan simulasi menggunakan Simulator AVSIM51 dari file latihan2.HEX:

1. Jalankan program Simulator AVSIM51 yaitu file eksekusi AVSIM51.EXE.

2. Pilih C untuk simulasi CPU target mikrokontroler 8031 .

3. Panggil (load) program Latihan2.HEX, dari menu utama pilih Load $\rightarrow$ Program dan tekan Enter, masukkan nama file dengan drive dan direktori file tersebut diletakkan.

4. Posisi alamat awal akan terlihat dari sinar kotak terang, dengan opcode pada bagian Operation untuk melompat ke alamat awal program, tekan F10 untuk eksekusi single-step dan menuju perintah pertama program. 
5. Untuk dapat mengamati eksekusi single-step pada subrutin TUNDA, pastikan bahwa kunci fungsi SKP dalam kondisi OFF, jika SKP dalam kondisi ON maka ubahlah menjadi OFF dengan menekan kunci fungsi F8.

6. Mengaktifkan siklus mesin, untuk melihat hitungan siklus mesin yang terjadi pada program, dari menu utama pilih Set $\rightarrow$ cYcles atau menekan SY.

7. Eksekusi setiap opcode secara single-step dengan menekan F10 dan amati dengan teliti setiap perubahan yang terjadi pada register-register, port-port dan memori yang terkait.

8. Jika terdapat perintah yang terlewat dan belum diamatinya, gunakan kunci fungsi <UNDO>F9, untuk mengembalikan ke eksekusi opcode sebelumnya, siklus mesin nilainya juga akan berubah pada posisi opcode tersebut.

Terdapat beberapa mnemonic untuk operasi aritmatika yang tidak dituliskan pada program, penulis memang membuat demikian agar Anda dapat membuat atau menambahkan sendiri sebagai latihan fungsi dari mnemonic tersebut.

\subsection{Menggunakan operasi eksternal I/O dari port-port mikrokontroler 8031}

Mikrokontroler 8031 juga dapat berkomunikasi dengan peralatan luar, misalnya membaca masukan sensor dari keluaran suatu ADC atau juga kombinasi saklar yang terpasang paralel pada masukan-masukan portportnya, mengirim sinyal untuk mengaktifkan suatu lampu atau relay.

60 Majalah Ilmiah Informatika, Vol. 4, No. 13, Desember 2002, Hal. 17-77 
Mikrokontroler 8031 dapat mengendalikannya melalui port-port yang dimilikinya. Port-port yang digunakan untuk komunikasi ke peralatan I/O adalah P3 (Port 3) dan P1 (Port 1) sedangkan P0 dan P2 digunakan untuk pengalamatan memori EPROM.

Program Port13.ASM berikut ini adalah contoh sederhana dari operasi I/O mikrokontroler 8031:

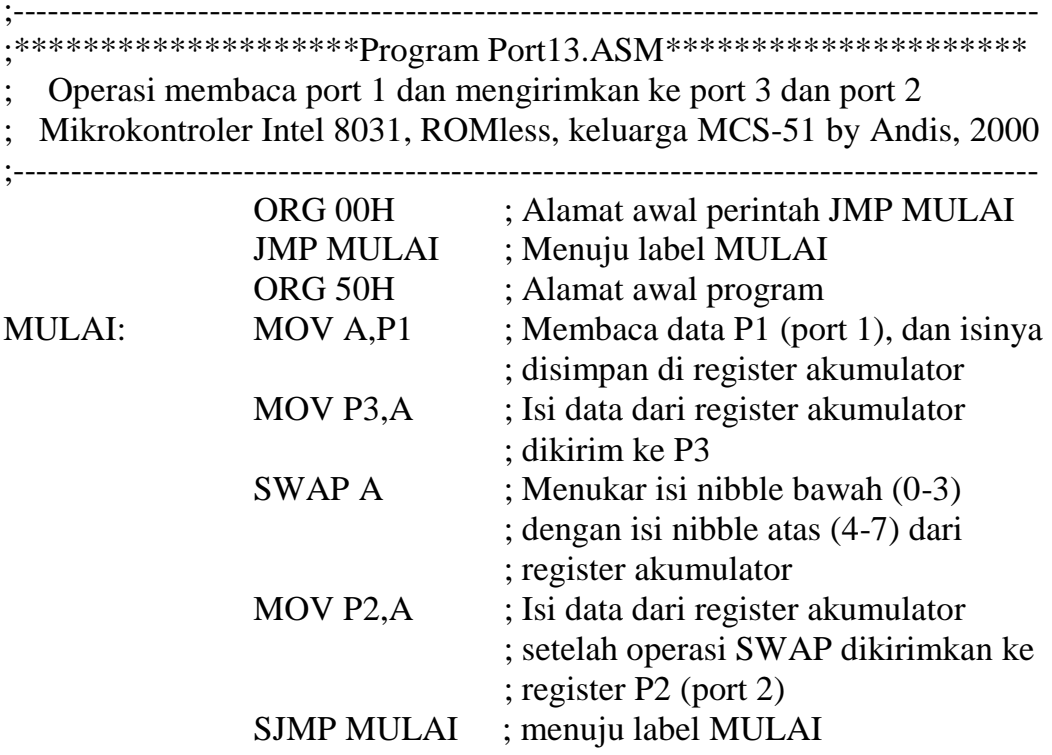

Setelah Anda menulis seluruh program simpan dengan nama file Port13.ASM. Ketika dijalankan program tersebut akan membaca P1 dan mengirim ke P3 dan P2 dengan hasil yang berbeda. Saat simulasi program, Anda dapat memasukkan sembarang nilai menuju P1 (port 1) melalui masukan keyboard dan melihat hasilnya melalui P3 dan P2.

Bagaimana menggunakan Program AVSIM51 Versi 1.30 untuk 61 Simulasi Mikrokontroller 8031 (Andi Susilo) 
Untuk melaksanakan simulasi, ubahlah file Port13.ASM menjadi file berekstensi Port13.HEX. Ikutilah prosedur berikut ini untuk mensimulasikan program Port13.HEX:

1. Menjalankan program Simulator AVSIM51 yaitu file eksekusi AVSIM51.EXE.

2. Memilih C untuk simulasi CPU target mikrokontroler 8031.

3. Memanggil (load) program Port13.HEX, dari menu utama pilih Load $\rightarrow$ Program dan tekan Enter, masukkan nama file dengan drive dan direktori file tersebut diletakkan.

4. Posisi alamat awal akan terlihat dari sinar kotak terang, dengan opcode pada bagian Operation untuk melompat ke alamat awal program, tekan F10 untuk eksekusi single- step dan menuju perintah pertama program.

5. Untuk program Port13.HEX akan dilakukan eksekusi terusmenerus menggunakan kunci fungsi $\langle\mathrm{GO}\rangle \mathrm{F} 1$, untuk saat ini jangan menekan tombol F1 terlebih dahulu.

Pastikan pula bahwa kecepatan eksekusi $<$ SPD $>$ F5 adalah HIgh.

6. Mengatur hitungan siklus mesin dari CPU target melalui menu utama Set $\rightarrow$ cYcles dan tekan Enter atau cukup menekan SY, sehingga siklus mesin aktif.

7. Program ini ketika dijalankan pertama kali akan membaca masukan dari P1 (port 1), nilai P1 (port 1) dapat diubah oleh pengguna melalui masukan keyboard, Anda hanya dapat mengisi atau mengedit P1 dalam modus display. Tekan Esc untuk masuk ke modus Display, dimana menu perintah utama di bagian bawah 
akan hilang dan CURSOR MENU akan berganti menjadi CURSOR HEX pada bagian sudut kanan atas.

8. Untuk mengedit port P1, harus dipindahkan kursor pada posisi port P1, gunakan kunci ekspress Alt-P, sekarang kursor akan berada pada port P1, Anda dapat mengedit bilangan dalam format hexa atau biner dengan nilai default FF:11111111, cobalah mengubah nilainya menjadi EF,55 atau berapapun.

9. Sekarang waktunya memulai simulasi. Tekan $\langle\mathrm{GO}\rangle \mathrm{F} 1$, lihat kondisi register dari $\mathrm{P} 1, \mathrm{P} 2$ dan $\mathrm{P} 3$, perhatikan juga program yang sedang dijalankan terus-menerus dengan melihat dari kotak putih terang yang selalu berubah.

10. Mengubah nilai dari port $\mathrm{P} 1$, apakah terjadi perubahan data pada port P2 dan P3?, ubah lagi nilainya sesuai keinginan. Untuk menghentikan eksekusi tekan F1 sekali lagi, maka program akan berhenti.

\subsection{Simulasi kontrol interupsi pada mikrokontroler 8031}

Terdapat dua jenis pengendalian terhadap waktu pembacaan suatu data yaitu Polled I/O dan I/O yang dikendalikan oleh interupsi. I/O yang dikendalikan interupsi memungkinkan mikroprosesor hanya melayani peralatan I/O, ketika interupsi terjadi. Setelah mikroprosesor menjalankan subrutin interupsi, maka mikroprosesor akan melanjutkan eksekusi program yang ditinggalkannya. Berbeda dengan Polled I/O dimana mikroprosesor selalu membaca atau menulis ke port, walaupun data tidak menspesifikasikan nilai tertentu tetapi data akan selalu valid.

Bagaimana menggunakan Program AVSIM51 Versi 1.30 untuk 63 Simulasi Mikrokontroller 8031 (Andi Susilo) 
Program sederhana berikut ini akan memperlihatkan bagaimana mensimulasikan kontrol interupsi pada mikrokontroler 8031 untuk INT 0 dan INT 1 menggunakan Simulator AVSIM51:

Program Int01.ASM
$;$; Program pengendalian interupsi INT 0 dan INT 1 dengan prioritas INT 0
$;$
$;$

\begin{tabular}{|c|c|c|}
\hline & ORG $00 \mathrm{H}$ & ; Alamat awal perintah JMP MULAI \\
\hline & JMP MULAI & ; Menuju label MULAI \\
\hline & ORG 03H & $\begin{array}{l}\text {; Alamat tabel vektor interupsi } \\
\text {; untuk INT } 0\end{array}$ \\
\hline & JMP INT0 & ; Menuju label INT0 \\
\hline & ORG 13H & $\begin{array}{l}\text {; Alamat tabel vektor interupsi } \\
\text {; untuk INT } 1\end{array}$ \\
\hline & JMP INT1 & ; Menuju label INT1 \\
\hline & ORG 40H & ; Alamat awal program \\
\hline MULAI: & MOV P2,\#0OH & ; Mengirim port $\mathrm{P} 2$ dengan data $00 \mathrm{H}$ \\
\hline & MOV PSW,\#0OH & $\begin{array}{l}\text {; Program Status Word berisi } 00 \mathrm{H}, \\
\text {; Bank } 0\end{array}$ \\
\hline & MOV R1,\#01H & ; Mengisi register $\mathrm{R} 1$ dengan data $01 \mathrm{H}$ \\
\hline & MOV@R1,\#32H & $\begin{array}{l}\text {; Mengisi data pada lokasi alamat yang } \\
\text {; ditunjukkan oleh register R1 dengan } \\
\text {; data } 32 \mathrm{H} \text { ( } 2 \text { desimal) }\end{array}$ \\
\hline INIT0: & MOV IE,\#85H & $\begin{array}{l}\text {; Inisialisasi untuk mengaktifkan } \\
\text {; Interupsi } 0 \text { dan } 1\end{array}$ \\
\hline & MOV IP,\#01H & ; Interupsi 0 sebagai prioritas tertinggi \\
\hline & SJMP MULAI & ; Melompat ke label MULAI \\
\hline INT0: & MOV P2,\#55H & ; Mengirim port $\mathrm{P} 2$ dengan data $55 \mathrm{H}$ \\
\hline & MOV PSW,\#0OH & $\begin{array}{l}\text {; Program Status Word berisi } 00 \mathrm{H} \text {, } \\
\text {; Bank } 0\end{array}$ \\
\hline & MOV R1,\#01H & ; Mengisi register R1 dengan $01 \mathrm{H}$ \\
\hline & MOV@R1,\#30H & $\begin{array}{l}\text {; Mengisi data pada lokasi alamat yang } \\
\text {; ditunjukkan oleh register R1 dengan } \\
\text {; data } 30 \mathrm{H} \text { ( } 0 \text { desimal) }\end{array}$ \\
\hline
\end{tabular}

64 Majalah Ilmiah Informatika, Vol. 4, No. 13, Desember 2002, Hal. 17-77 
RETI ; Kembali ke program utama semula

INT1: $\quad$ MOV P2,\#AAH ; Mengirim port P2 dengan data AAH

MOV PSW,\#00H; Program Status Word berisi 00H, ; Bank 0

MOV R1,\#01H ; Mengisi register R1 dengan 01H

MOV@R1,\#31H; Mengisi data pada lokasi alamat yang

; Ditunjukkan oleh register R1 dengan

; data $31 \mathrm{H}$ (1 desimal)

RETI ; Kembali ke program utama semula

Setelah program ditulis, simpan program dengan nama file Int01.ASM. Ubahlah file Int01.ASM menjadi file berekstensi Int01.HEX agar dapat disimulasikan dengan AVSIM51. Port P3 terletak pada pena 10-17 dari kemasan DIP mikrokontroler 8031, pena 12 dan 13 masingmasing untuk INT0 dan INT1. Ketika program ini sedang dijalankan, harus diberikan sinyal aktif rendah kepada salah satu pena masukan interupsi yang terletak pada bit ke-3 dan ke-4 dari Port P3 dari program simulator AVSIM51, agar perubahan kondisi dapat diamati ketika interupsi terjadi. Berikut ini adalah prosedur untuk mensimulasikan kontrol interupsi melalui program Int01.HEX:

1. Menjalankan program Simulator AVSIM51 yaitu file eksekusi AVSIM51.EXE.

2. Memilih C untuk simulasi CPU target mikrokontroler 8031.

3. Memanggil (load) program Int01.HEX, dari menu utama pilih Load $\rightarrow$ Program dan tekan Enter, masukkan nama file dengan drive dan direktori file tersebut diletakkan.

4. Posisi alamat awal akan terlihat dari sinar kotak terang, dengan

Bagaimana menggunakan Program AVSIM51 Versi 1.30 untuk 65 Simulasi Mikrokontroller 8031 (Andi Susilo) 
opcode pada bagian Operation untuk melompat ke alamat awal program, tekan F10 untuk eksekusi single- step dan menuju perintah pertama program.

5. Untuk program Int01.HEX akan dilakukan eksekusi terusmenerus menggunakan kunci fungsi $\langle\mathrm{GO}\rangle \mathrm{F} 1$, untuk saat ini, jangan menekan tombol F1 terlebih dahulu.

Pastikan pula bahwa kecepatan eksekusi <SPD>F5 adalah HIgh.

6. Mengatur hitungan siklus mesin dari CPU target melalui menu utama Set $\rightarrow$ cYcles dan tekan Enter atau cukup menekan SY, sehingga siklus mesin aktif.

7. Untuk mendapatkan suatu interupsi dari suatu peralatan $\mathrm{I} / \mathrm{O}$, maka peralatan I/O tersebut harus dihubungkan ke pena-pena interupsi dari mikrokontroler 8031 secara nyata. Tetapi menggunakan Simulator AVSIM51, cukup memberikan sinyal aktif rendah ke port P3 pada bit ke-3 untuk INT0 dan bit ke-4 untuk INT1 melalui masukan keyboard. Hal itu akan sama terjadi apabila diterapkan kepada rangkaian minimum mikrokontroler 8031 yang sesungguhnya. Register-register, port-port dan memori dapat diubah secara langsung dari masukan keyboard hanya dalam modus Display. Tekan Esc untuk masuk ke modus Display, dan akan terlihat menu perintah utama di bagian bawah hilang dan CURSOR MENU akan berganti menjadi CURSOR HEX pada bagian sudut kanan atas.

8. Memindahkan kursor menuju port P3 menggunakan kunci ekspress Alt-Q, Anda dapat lakukan pengubahan dari bagian hexadecimal ataupun biner. Kondisi default port P3 adalah

66 Majalah Ilmiah Informatika, Vol. 4, No. 13, Desember 2002, Hal. 17-77 
FF: <simbol ASCII>:11111111, sekarang dapat diubah nilai P3 sesuai yang keinginan.

9. Mensimulasikan program Int01.HEX dengan menekan kunci fungsi $\langle\mathrm{GO}\rangle$ F1. Perhatikan kondisi awal ketika belum terjadi interupsi, lokasi alamat yang ditunjukkan oleh register R1 (lokasi alamat $0001 \mathrm{H}$ di area 1 (jangkauan memori 0000H-001FH), Bank 0) berisi data $32 \mathrm{H}$ (tampilan kode ASCII adalah bilangan desimal 2).

10. Memberikan sinyal aktif rendah bit ke-3 dari port P3 untuk INT0, apakah terjadi perubahan data pada lokasi alamat $0001 \mathrm{H}$ di area 1 (memori 0000H-001FH)?, untuk menguji dengan mudah lihatlah apakah tampilan kode ASCII bernilai desimal 0. Lakukan cara yang sama untuk INT1 dengan memberikan sinyal aktif rendah pada bit ke-4 dan bit ke-3 harus berlogika tinggi.

11. Apakah yang terjadi jika diberikan sinyal aktif rendah pada bit ke-3 INT0 dan bit ke-4 INT1 dari port P3?

12. Jika terjadi kesalahan, dan ingin mengulang eksekusi program, tekan Esc untuk mengubah ke CURSOR MENU. Dan resetlah program dengan melalui perintah utama Reset $\rightarrow \mathrm{Cpu}$ (Enter) atau cukup menekan RC. Untuk eksekusi program tekan kembali Esc untuk berpindah ke modus display. Selanjutnya tekan F1 untuk memulai eksekusi program dan tekan F1 kembali untuk mengakhiri eksekusi program.

Bagaimana menggunakan Program AVSIM51 Versi 1.30 untuk 
Contoh program kedua berikut ini akan memberikan pengalaman tentang inisialisasi interupsi. Program Int012.ASM meminta Anda untuk memasukkan nilai ke port P1 (inisialisasi interupsi) dan port P3 (Rutin Pelayanan Interupsi). Beberapa kombinasi untuk masukan P1 melalui keyboard:

$\begin{array}{ll}\mathrm{P} 1 & \text { Interupsi } \\ 00 \mathrm{H} & \text { INT 0 } \\ 01 \mathrm{H} & \text { INT 1 } \\ 02 \mathrm{H} & \text { Netral }\end{array}$

Keterangan:

- Netral berarti inisialisasi interupsi sebelumnya masih berlaku.

- INT 1 dapat dimungkinkan untuk masukan P1 selain 00H dan 02H misalnya $03 \mathrm{H}, 04 \mathrm{H}, 05 \mathrm{H}, 11 \mathrm{H}$ dan seterusnya.

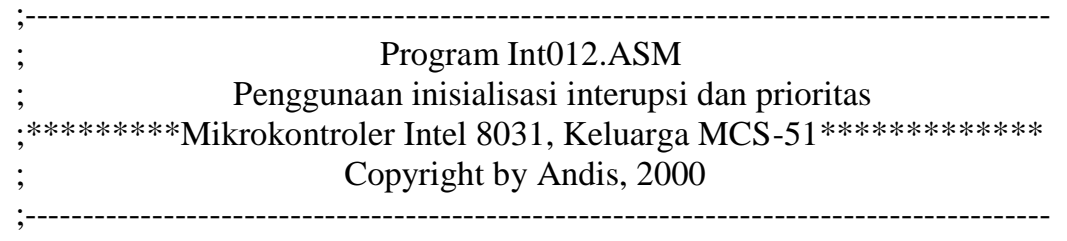

$\begin{array}{ll}\text { ORG 00H } & \text {; Alamat awal perintah JMP MULAI } \\ \text { JMP MULAI } & \text {; Menuju label MULAI } \\ \text { ORG 03H } & \text {; Alamat tabel vektor interupsi } 0 \\ \text { JMP INT0 } & \text {; Menuju label INT0 } \\ \text { ORG 13H } & \text {; Alamat tabel vektor interupsi 1 } \\ \text { JMP INT1 } & \text {; Menuju label INT1 } \\ \text { ORG 40H } & \\ \text { MOV P2,\#00H } & \text {; Mengirim port P2 dengan data 00H } \\ \text { MOV PSW,\#00H } \text {; Program Status Word bernilai 00H, } & \text {; Bank 0 } \\ \text { MOV R1,\#01H } & \text {; Mengisi register R1 dengan data 01H }\end{array}$

68 Majalah Ilmiah Informatika, Vol. 4, No. 13, Desember 2002, Hal. 17-77 
MOV @R1,\#32H; Mengisi lokasi alamat yang

; ditunjukkan oleh register R1 dengan

; data $32 \mathrm{H}$

MOV A,P1 ; Membaca data dari port P1 dan

; disimpan di akumulator

MOV R0,A ; Mengisi register R0 dengan data dari

; akumulator

JZ INIT0 ; j Jika akumulator berisi 00H menuju

; label INIT0

CJNE R0,\#02H,INIT1 ; Jika R0<>02H menuju label

; INIT1

SJMP MULAI ; Menuju label MULAI

INIT0:

MOV IE,\#81H

; Inisialisasi untuk aktif

; Interupsi 0

MOV IP,\#01H

; Prioritaskan interupsi 0

JMP MULAI

INIT1:

MOV IE,\#84H

; Inisialisasi untuk aktif

; Interupsi 1

MOV IP,\#04H

; Prioritaskan interupsi 1

JMP MULAI

INT0:

MOV P2,\#55H ; Mengirim port $\mathrm{P} 2$ dengan data $55 \mathrm{H}$

MOV@R1,\#30H; Mengisi lokasi alamat yang

; ditunjukkan register R1 dengan

; data $30 \mathrm{H}$

RETI ; Kembali ke program utama semula

INT1: $\quad$ MOV P2,\#AAH ; Mengirim port P2 dengan data AAH MOV@R1,\#31H; Mengisi lokasi alamat yang

; ditunjukkan register R1 dengan

; data $31 \mathrm{H}$

RETI ; Kembali ke program utama semula

Simpan program dengan nama file Int012.ASM, dan ubahlah menjadi file berekstensi Int012.HEX. Melaksanakan prosedur yang sama

Bagaimana menggunakan Program AVSIM51 Versi 1.30 untuk 69 Simulasi Mikrokontroller 8031 (Andi Susilo) 
seperti saat mensimulasikan program Int01.HEX. Masukan melalui keyboard port P1 dengan kombinasi yang diberikan diatas, setelah itu berikan sinyal aktif rendah kepada interupsi yang akan dilaksanakan melalui port P3 bit ke-4 untuk INT 1 atau bit ke-3 untuk INT 0 .

\subsection{Simulasi penggunaan Timer pada Mikrokontroler 8031}

Timer digunakan salah satunya sebagai pewaktu dari suatu kerja alat, misalnya untuk pewaktuan temperatur suhu Inkubator penetas telur, pewaktu generator tegangan tinggi dan lain-lain. Program berikut ini menggunakan timer 0 untuk menghidupkan lampu LED selama satu detik, kemudian dimatikan selama satu detik dengan frekuensi hidup-mati sebesar 0,5 Hertz.

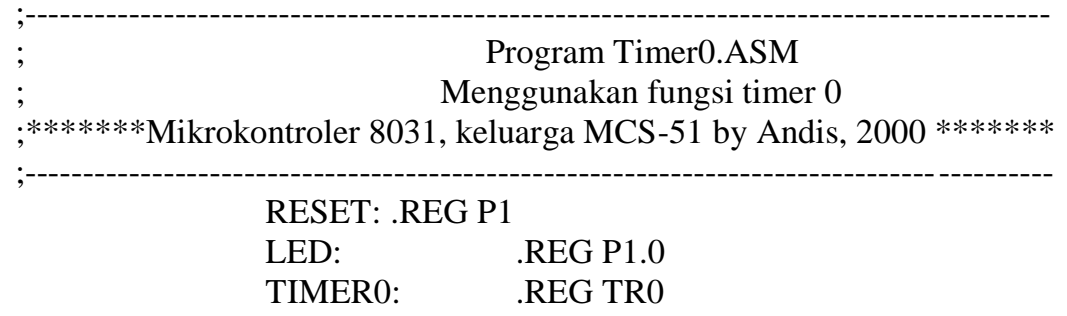

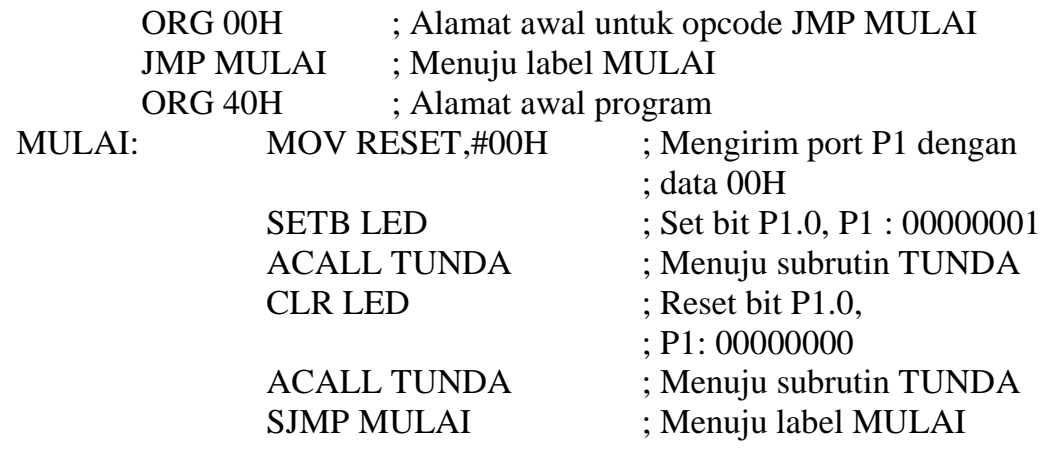

70 Majalah Ilmiah Informatika, Vol. 4, No. 13, Desember 2002, Hal. 17-77 
TUNDA: $\quad$ MOV R0,\#00H ; Mengisi register R0 dengan 00H, ; awal hitungan

INIT:

$\begin{array}{ll}\text { MOV TMOD,\#01H } & ; \text { Timer 0, Mode 1/Timer } 16 \\ & ; \text { bit, masukan dari system } \\ & ; \text { clock internal } \\ \text { MOV TH0,\#0D8H } & \text {; Mengisi register TH0 } \\ & \text {; dengan data D8H } \\ \text { MOV TL0,\#0EFH } & \text {; Mengisi register TL0 } \\ & \text {; dengan data EFH }\end{array}$
SETB TIMER0 ; Set bit TR0 untuk mengaktifkan ; Timer 0
BACA: NOP ; Tidak ada operasi
JBC TF0,UJI ; Jika bit TF0 (Timer 0 overflow flag)
$;=1$ menuju label UJI, selang waktu
; 0,01 detik
SJMP BACA ; Menuju label BACA
UJI: $\quad$ INC R0 ; Menaikkan satu isi dari register R0
CJNE R0,\#64H,INIT ; Jika R0<>64H menuju label ; INIT
RET ; Kembali ke program utama semula

Simpan program dengan nama file Timer0.ASM, kemudian ubahlah file menjadi Timer0.HEX agar dapat disimulasikan oleh simulator AVSIM51. Ikutilah prosedur berikut ini untuk simulasi program Timer0.HEX dengan Simulator AVSIM51:

1. Menjalankan program Simulator AVSIM51 yaitu file eksekusi AVSIM51.EXE.

2. Memilih C untuk simulasi CPU target mikrokontroler 8031.

3. Memanggil (load) program Timer0.HEX, dari menu utama pilih Load $\rightarrow$ Program dan tekan Enter, masukkan nama file dengan drive dan direktori file tersebut diletakkan.

Bagaimana menggunakan Program AVSIM51 Versi 1.30 untuk 71 Simulasi Mikrokontroller 8031 (Andi Susilo) 
4. Posisi alamat awal akan terlihat dari sinar kotak terang, dengan opcode pada bagian Operation untuk melompat ke alamat awal program, tekan F10 untuk eksekusi single- step dan menuju perintah pertama program.

5. Untuk program Timer0.HEX akan dilakukan eksekusi terusmenerus menggunakan kunci fungsi $\langle\mathrm{GO}\rangle \mathrm{F} 1$, untuk saat ini, jangan menekan tombol F1 terlebih dahulu. Pastikan pula bahwa kecepatan eksekusi <SPD>F5 adalah HIgh.

6. Mengatur hitungan siklus mesin dari CPU target melalui menu utama Set $\rightarrow$ cYcles (Enter) atau cukup menekan SY, sehingga siklus mesin aktif.

7. Untuk memberikan suatu pewaktuan kepada suatu peralatan $\mathrm{I} / \mathrm{O}$, maka peralatan I/O tersebut harus dihubungkan ke pena-pena timer (T0 dan T1) dari mikrokontroler 8031 secara nyata jika menggunakan sistem clock eksternal. Program Timer0.HEX menggunakan sistem clock internal, sehingga tidak menggunakan pena-pena T0 atau T1 dari CPU target. Satu-satunya bagian program yang harus dimasukkan nilainya melalui keyboard adalah bit TF0 (Timer 0 overflow flag), Jika sistem clock internal telah menghitung nilai pewaktuan yang dispesifikasikan melalui register THO dan TLO dalam program ini ditentukan pewaktuan selama 0,01 detik, maka bit TF0 akan bernilai 1 artinya perhitungan nilai telah lewat. Register-register, port-port dan memori dapat diubah secara langsung dari masukan keyboard hanya dalam modus Display. Tekan Esc untuk masuk ke modus Display, dan menu perintah utama di bagian bawah akan hilang,

72 Majalah Ilmiah Informatika, Vol. 4, No. 13, Desember 2002, Hal. 17-77 
CURSOR MENU akan berganti menjadi CURSOR HEX pada bagian sudut kanan atas.

8. Setelah masuk kedalam modus display, pindahkan kursor menuju register Timer Control (TCON) dengan menekan kunci ekspress Ctrl-T dan posisikan kursor pada bit TF0 untuk timer 0 .

9. Sekarang simulasikan program dengan menekan $\langle\mathrm{GO}\rangle \mathrm{F} 1$, perhatikan register $\mathrm{R} 0$ masih berisi $00 \mathrm{H}$, berikan bit 1 pada TF0, perhatikan perubahan yang terjadi pada isi register R0 yang menjadi $01 \mathrm{H}$, berikan logika 1 kembali pada TF0 sampai R0 mencapai $64 \mathrm{H}$ dan lihat perubahan yang terjadi pada port $\mathrm{P} 1$.

10. Jika terjadi kesalahan dan ingin mengulangi eksekusi program, tekan F1 untuk menghentikan program, tekan Esc untuk mernampilkan menu perintah dan reset program yaitu pilih Reset $\rightarrow$ Cpu dan tekan Enter. Untuk menjalankan program kembali masuk ke modus display dengan menekan Esc, dan tekan F1 untuk mulai eksekusi program.

Cobalah dengan membuat program kedua menggunakan Timer 1, penulisan programnya sama seperti TimerO.ASM, tetapi dengan mengganti data register TMOD menjadi $10 \mathrm{H}$, register TH0 dan TL0 diganti menjadi TH1 dan TL1, register TF0 diganti menjadi TF1. Simpan program dengan nama file Timer1.ASM, ubahlah file menjadi Timer1.HEX. Selanjutnya eksekusi program seperti prosedur diatas dan berikan logika 1 pada bit TF1.

Bagaimana menggunakan Program AVSIM51 Versi 1.30 untuk 73 Simulasi Mikrokontroller 8031 (Andi Susilo) 


\subsection{Simulasi penggunaan Counter pada Mikrokontroler 8031.}

Counter digunakan untuk menghitung jumlah pulsa yang masuk pada pena-pena $\mathrm{T} 0$ atau $\mathrm{T} 1$, dapat juga digunakan untuk menghitung frekuensi dari sinyal yang masuk dengan salah satu timer digunakan sebagai pewaktu satu detik.

Program berikut ini akan menghitung jumlah pulsa yang masuk dari pena-pena $\mathrm{T} 0$ dan $\mathrm{T} 1$ :

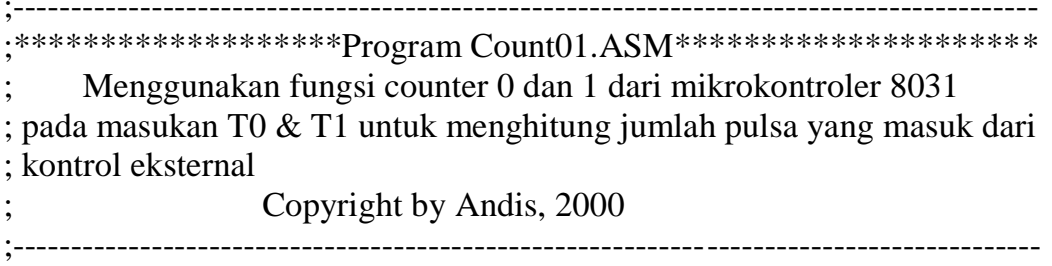

INDIC0: .REG P1

INDIC1: .REG P2

COUNTER0: .REG TR0

COUNTER1: .REG TR1

MULAI:

$\begin{array}{ll}\text { ORG 00H } & \text {; Alamat awal opcode JMP MULAI } \\ \text { JMP MULAI } & \text {; menuju label MULAI } \\ \text { ORG 40H } & \text {; Alamat awal program }\end{array}$

74 Majalah Ilmiah Informatika, Vol. 4, No. 13, Desember 2002, Hal. 17-77 
; perhitungan register TL1

; dari masukan timer 1 (T1)

MOV INDIC1,A $\quad$; Isi akumulator dikirim

; ke port P2

SJMP UJI ; Menuju label UJI

Setelah menulis seluruh program, simpan program dengan nama file Count01.ASM, kemudian ubahlah file tersebut menjadi berekstensi Count01.HEX. Prosedur berikut ini menjelaskan bagaimana mensimulasikan program Count01.HEX:

1. Menjalankan program Simulator AVSIM51 yaitu file eksekusi AVSIM51.EXE.

2. Memilih C untuk simulasi CPU target mikrokontroler 8031 .

3. Memanggil (load) program Count01.HEX, dari menu utama pilih Load $\rightarrow$ Program dan tekan Enter, masukkan nama file dengan drive dan direktori file tersebut diletakkan.

4. Posisi alamat awal akan terlihat dari sinar kotak terang, dengan opcode pada bagian Operation untuk melompat ke alamat awal program, tekan F10 untuk eksekusi single- step dan menuju perintah pertama program.

5. Untuk program Count01.HEX akan dilakukan eksekusi terus-menerus menggunakan kunci fungsi $\langle\mathrm{GO}\rangle \mathrm{F} 1$, untuk saat ini, jangan menekan tombol F1 terlebih dahulu, kecuali jika telah mengerti cara simulasinya. Pastikan pula bahwa kecepatan eksekusi $<$ SPD $>$ F5 adalah HIgh.

Bagaimana menggunakan Program AVSIM51 Versi 1.30 untuk 
6. Mengatur hitungan siklus mesin dari CPU target melalui menu utama Set $\rightarrow$ cYcles dan tekan Enter atau cukup menekan SY, sehingga siklus mesin aktif.

7. Ketika eksekusi sedang dijalankan, program ini akan menghitung jumlah pulsa yang masuk dari pena T0 dan T1, jumlah pulsa yang masuk diletakkan pada register TL0 untuk counter 0 dan TL1 untuk counter 1. Dalam simulasi dengan AVSIM51, Anda yang memberikan pulsa ke port P3 bit ke-5 untuk T0 dan bit ke-6 untuk T1 dengan sinyal aktif rendah melalui keyboard. Tekan Esc untuk berpindah ke modus display, selanjutnya pindahkan kursor ke port P3 dengan menekan kunci ekspress Alt-Q.

8. Mensimulasikan program dengan menekan kunci fungsi $\langle\mathrm{GO}\rangle \mathrm{F} 1$, dan berikan sinyal aktif rendah ke port P3 pada bit ke-5 (T0) atau bit ke-6 (T1), lihatlah perhitungan jumlah sinyal yang masuk melalui register TL0 atau TL1, perhitungan juga ditampilkan pada port P1 dan P2.

9. Jika program ingin dihentikan tekan F1, maka eksekusi program akan berhenti. Berlatihlan terus-menerus sampai memahami cara kerjanya.

Program AVSIM51 memiliki menu Help yang terdapat pada bagian menu utama program terdiri dari empat submenu sebagai berikut :

1. Commands berisi Command Mode Menu menjelaskan tentang Control, Enter Expression, Enter mnemonic, Editing Keys dan Breakpoints.

2. Display berisi penjelasan Mode Control Keys, Express Keys, Cursor Control Keys dan Object Editing Keys.

76 Majalah Ilmiah Informatika, Vol. 4, No. 13, Desember 2002, Hal. 17-77 
3. Simulation berisi penjelasan untuk Function Keys, Simulation Control dan Toggle Control.

4. Avocet berisi penjelasan informasi produk dari AVSIM, nama perusahaan dan alamatnya, komputer yang mendukung AVSIM dan beberapa target CPU yang dapat disimulasikan oleh program AVSIM.

Bagian fungsi dari program bantu AVSIM51 yang telah penulis jelaskan, kiranya sudah dapat memberikan keterampilan bagi pembaca bagian penting dalam mensimulasikan program perangkat lunak mikrokontroler 8031, tidak ada pernyataan yang lebih bijaksana kecuali segera mencoba membuat program untuk aplikasi mikrokontroler 8031 dan mensimulasikan program tersebut dengan AVSIM51, mudahmudahan berhasil.

\section{Daftar Pustaka}

1. Moh. Ibnu Malik \& Anistardi, Bereksperimen dengan Mikrokontroler 8031, Penerbit ELEX MEDIA KOMPUTINDO, Jakarta, 1997.

2. AVOCET SYSTEM INC 120 Union St. Rockport, Maine 04856 USA, AVSIM51 8051 Family User's Manual Ver. 1.2, November 1986.

3. MICROPORT Computer Research Co., Ltd, INTRODUCTION TO BGC-8088 MICROENGINEER V.30 USER'S GUIDE AND EXPERIMENTS, Tainan City, Taiwan.

4. Elektuur, DATA SHEET BOOK 1 data IC LINIER, TTL dan CMOS (Kumpulan data penting komponen elektronika), alih bahasa oleh Wasito S, Penerbit PT ELEX MEDIA KOMPUTINDO, Kelompok GRAMEDIA, cetakan ketiga, Jakarta, Januari 1994.

5. Intel Corporation, Development Solutions MCS-51 Macro Assembler, User's Guide for DOS System, 3065 Bowers Avenue, Santa Clara, CA 95051, 1986.

Bagaimana menggunakan Program AVSIM51 Versi 1.30 untuk 77 Simulasi Mikrokontroller 8031 (Andi Susilo) 